\title{
Synthetic Compounds with 2-Amino-1,3,4-Thiadiazole Moiety Against Viral Infections
}

\author{
Georgeta Serban (1)
}

Pharmaceutical Chemistry Department, Faculty of Medicine and Pharmacy, University of Oradea, 29 Nicolae Jiga, 410028 Oradea, Romania; getaserban_2000@yahoo.com; Tel.: +4-0756-276-377

Academic Editor: Antonio Carta

Received: 29 January 2020; Accepted: 18 February 2020; Published: 19 February 2020

\begin{abstract}
Viral infections have resulted in millions of victims in human history. Although great efforts have been made to find effective medication, there are still no drugs that truly cure viral infections. There are currently approximately 90 drugs approved for the treatment of human viral infections. As resistance toward available antiviral drugs has become a global threat to health, there is an intrinsic need to identify new scaffolds that are useful in discovering innovative, less toxic and highly active antiviral agents. 1,3,4-Thiadiazole derivatives have been extensively studied due to their pharmacological profile, physicochemical and pharmacokinetic properties. This review provides an overview of the various synthetic compounds containing the 2-amino-1,3,4-thiadiazole moiety that has been evaluated for antiviral activity against several viral strains and could be considered possible prototypes for the development of new antiviral drugs.
\end{abstract}

Keywords: 2-amino-1,3,4-thiadiazole; viral infections; antiviral agents; drug resistance; inhibitory concentration; mechanism of action

\section{Human Viral Infections}

Viruses are the smallest among all self-replicating organisms and yet they are the etiological agents of many difficult to treat diseases in human populations [1]. There are broad types of human infections caused by viruses, such as respiratory infections (common cold, Influenza), digestive infections (viral gastroenteritis), central nervous system infections (viral meningitis, viral encephalitis), skin or mucosal infections (herpes, measles, mumps, smallpox and rubella), hepatic infections (hepatitis A, B, C, E), blood infections (acquired immunodeficiency syndrome) and hemorrhagic fever (yellow fever, Ebola hemorrhagic fever). Viruses are the most abundant and diverse biological entities on Earth and this is the reason for the high incidence of viral infections [2]. In addition, some viruses are etiological agents in the development of human tumors, particularly cervical cancer and hepatic cancer [3].

The main method and most cost-effective strategy for preventing viral infections is through vaccination, which is meant to prevent outbreaks by increasing immunity [4]. Vaccines for the prevention of several common acute viral infections, such as polio, rubella, measles, mumps, Influenza, yellow fever, encephalitis, rabies, smallpox and hepatitis B were developed during the 20th century and are available on a large scale [1,4]. Efforts to develop safe and effective vaccines against viruses that cause chronic infections, such as human immunodeficiency virus or hepatitis $C$ virus did not give the expected results $[1,4,5]$.

For many viral infections, only symptomatic treatment is indicated, while it is expected the immune system to fight off the virus. However, there are high-virulence viruses that cause serious viral infections where antiviral treatment is essential for patient survival. Although great efforts have been made to find effective medication, there are still no drugs that truly cure viral infections. Moreover, 
due to the ability of viruses to undergo rapid mutations, the mechanisms involved in developing resistance to antiviral drugs are activated in most cases [1,3]. As resistance toward antiviral drugs is becoming a global health threat, there is an intrinsic need to identify new scaffolds that are useful in discovering innovative, less toxic and highly active antiviral agents $[3,6,7]$.

\section{Nitrogen-Containing Heterocycles and Thiadiazole Ring in Biology and Medicinal Chemistry}

Nitrogen-containing heterocycles are widely distributed in nature and are essential in vegetal and animal metabolism. They are found in nucleic acids, vitamins, antibiotics, alkaloids, etc. [8-14]. In addition, nitrogen-containing heterocycles are important targets for medicinal chemistry, as they are found in more than half of the commercially available drugs and can also act as versatile intermediates in the synthesis of complex products that exhibit outstanding biological activities [15]. Most of the nitrogen-containing heterocyclic compounds exhibit better biological activity than non-nitrogen compounds $[12,16,17]$. Currently, there are approximately 90 drugs approved for use in the treatment of nine human viral infections caused by human immunodeficiency virus (HIV), hepatitis B virus (HBV), hepatitis $\mathrm{C}$ virus (HCV), herpes simplex virus (HSV), Influenza virus, human cytomegalovirus (HCMV), varicella-zoster virus (VZV), respiratory syncytial virus (RSV) and human papillomavirus [18]. Most of these drugs (e.g., acyclovir, cidofovir, idoxuridine, nevirapine, pleconaril, ribavirin, etc.) are nitrogen heterocycle molecules $[3,19]$.

Five-membered aromatic systems with three heteroatoms at symmetrical positions, such as the 1,3,4-thiadiazole ring, have been extensively studied due to their pharmacological profile and physicochemical and pharmacokinetic properties. 1,3,4-Thiadiazole derivatives are known as compounds having significant and diverse biological activities such as antibacterial, antifungal, antitubercular [20], analgesic and anti-inflammatory [21,22], antidepressant and anxiolytic [23], kinesin inhibitors [24], etc. The 1,3,4-thiadiazole ring is also found in several medicines such as acetazolamide, methazolamide, cefazolin, cefazedone, sulfamethizole or megazol [20,25-27]. The 1,3,4-thiadiazole nucleus provides the compounds with high lipophilicity and the ability to form mesoionic systems associated with discrete regions of positive and negative charges. These distinct features allow mesoionic compounds to efficiently cross cellular membranes, leading to good oral absorption, bioavailability and strong unique interactions with biological molecules (e.g., DNA, proteins, etc.) thus increasing the potential of 1,3,4-thiadiazole derivatives to exhibit biological activities [20,27-29]. The thiadiazole ring is a bioisostere of the pyrimidine and pyridazine rings. The pyrimidine nucleus is commonly found in naturally occurring compounds of biochemical importance, as well as in drugs (e.g., pyrimidine nucleosides and nucleotides, nucleic acids, antiviral drugs), while the pyridazine nucleus is a component of some pharmacologically active compounds [20,30-32]. The thiadiazole ring also acts as a bioisostere of the thiazole ring, and therefore thiadiazole derivatives can act in the same way as third- and fourth-generation antibacterial cephalosporins. This is an additional feature that highlights the high potential of this ring system in medicinal chemistry $[20,28]$. Many researchers suppose there is a connection between the biological potential of 1,3,4-thiadiazoles and the strongly aromatic character of the 1,3,4-thiadiazole ring, as well as the presence of the toxophoric $=\mathrm{N}$-C-Slinkage group. Furthermore, the high in vivo stability and low toxicity for higher organisms are also attributed to the 1,3,4-thiadiazole ring [20,33,34]. In addition, the amine derivatives of 1,3,4-thiadiazole are also studied. 2-Amino-1,3,4-thiadiazole moiety and its derivatives are known for their antitumor, antitrypanosomal and uricogenic properties [20,25,27,35-38]. 2-Amino-1,3,4-thiadiazole derivatives are currently being synthesized in many laboratories, and in previous papers, we described several 2-amino-1,3,4-thiadiazoles that exhibit antibacterial, antifungal, antitubercular [20,39-44], and antiparasitic activities [27,38]. The purpose of this paper is to present some small molecules possessing the 2-amino-1,3,4-thiadiazole moiety that have shown antiviral activity. 


\section{The Activity of 2-Amino-1,3,4-Thiadiazole Derivatives Against Human Viral Pathogens}

\subsection{Human Immunodeficiency Virus (HIV)}

About 37 million people infected with human immunodeficiency virus (HIV) (Retroviridae family) were reported in 2016 [45], with the highest incidence of infection in sub-Saharan Africa. In the Third World, HIV infection coupled with tropical diseases, malaria and tuberculosis causes a high level of mortality. Due to sexual transmission, acquired immunodeficiency syndrome (AIDS) affects many young workers and therefore the disease has not only a social impact, but also a significant economic impact in these regions [3].

In the past two and half decades, different organic compounds have been developed as drug candidates for the treatment of AIDS targeting one or more stages of the virus life cycle such as absorption, fusion, entry, un-coating, reverse transcription, integration, transcription and maturation [46]. HIV-1 reverse transcriptase (RT) is an essential enzyme that converts single-stranded RNA from the viral genome into double-stranded DNA before its integration into host DNA [47]. Since RT is a key enzyme in the life cycle of HIV-1, some HIV-1 RT inhibitors with nucleoside or non-nucleoside structures are currently used in AIDS treatment [48]. Nucleoside reverse transcriptase inhibitors (NRTIs) such as zidovudine, didanosine, zalcitabine, stavudine, lamivudine, abacavir, tenofovir or emtricitabine interact competitively with the catalytic site of the RT, while the non-nucleoside reverse transcriptase inhibitors (NNRTIs)—nevirapine, delavirdine, efavirenz, etc.-follow an allosteric interaction with a site adjacent to the NRTI binding site, the non-nucleoside inhibitor binding site (NNBS) [47]. Due to their high selectivity and low cytotoxicity, NNRTIs have gained an increasingly important role in HIV infection therapy [49]. Five drugs in the class of NNRTIs have been approved for the treatment of HIV infection: nevirapine, delavirdine and efavirenz as the first generation drugs and etravirine (Intelence tablets, Janssen Therapeutics Company, 2008) and rilpivirine (Edurant tablets, Janssen Therapeutics Company, 2011) as the next-generation NNRTIs [46,50-52]. Doravirine (MK-1439A) is a new NNRTI developed by Merck Company that completed two 48-week studies in 2017 [53]. Doravirine demonstrated antiretroviral activity and immunological effects similar to efavirenz with significantly fewer central nervous system adverse events [54]. In January 2018, US Food and Drug Administration (FDA) accepted for review two new drug applications (NDAs) for doravirine, as a once-daily tablet in combination with other antiretroviral agents and as a once-daily fixed-dose combination single tablet of doravirine with lamivudine and tenofovir disoproxil fumarate [55]. On 30 August 2018, FDA approved both applications of doravirine for AIDS treatment as Pifeltro tablets (doravirine $100 \mathrm{mg}$ ) and Delstrigo tablets (doravirine $100 \mathrm{mg}$, lamivudine $300 \mathrm{mg}$ and tenofovir disoproxil fumarate $300 \mathrm{mg}$ ) [56,57]. Several NNRTIs (e.g., fosdevirine, lersivirine) underwent clinical development programs but were discontinued due to unfavorable pharmacokinetic, efficacy and/or safety factors [58-60].

Approximately 17 million patients have access to antiretroviral therapy capable of controlling viremia and reducing mortality [61]. However, long-term treatment with antiretroviral agents can lead to drug resistance due to rapid mutations in the viral genome resulting in RT mutations and HIV chemotherapy failure [62]. These concerns have attracted a particular focus on research into new antiretroviral drugs that address the limitations of currently available agents for the treatment of HIV infection $[46,59]$.

As a bioisostere of pyrimidine, a nucleoside component of nucleic acids, the thiadiazole ring can impart antiviral activity [28]. Studies concerning the antiviral activity of 1,3,4-thiadiazole derivatives often gave compounds with moderate or lower in vitro anti-HIV-1 and anti-HIV-2 activity than the reference drugs [63,64]. A relevant example is the chiral 2-substituted 5-(4-chlorophenylamino)-1,3,4-thiadiazoles 1-5 synthesized by Akhtar et al. by acidic cyclodehydration of the corresponding thiosemicarbazides [65]. 
<smiles>[R]C(NS(=O)(=O)c1ccc(C)cc1)c1nnc(Nc2ccc(Cl)cc2)s1</smiles>

$$
\begin{aligned}
\mathrm{R}= & \mathrm{CH}\left(\mathrm{CH}_{3}\right)_{2}(\mathbf{1}) ; \quad \mathrm{CH}_{2} \mathrm{CH}\left(\mathrm{CH}_{3}\right)_{2}(\mathbf{2}) ; \mathrm{CH}\left(\mathrm{CH}_{3}\right) \mathrm{CH}_{2} \mathrm{CH}_{3}(\mathbf{3}) \\
& \mathrm{CH}(\mathrm{OH}) \mathrm{CH}_{3}(\mathbf{4}) ; \mathrm{CH}_{2} \mathrm{CH}_{2} \mathrm{SCH}_{3} \text { (5) }
\end{aligned}
$$

In vitro HIV inhibitory activity using human T-lymphocyte (MT-4) cells gave moderate or low half-maximal effective concentration $\left(\mathrm{EC}_{50}\right)$ values in comparison to efavirenz $\left(\mathrm{EC}_{50}\right.$ value of $0.003 \mu \mathrm{g} / \mathrm{mL}$ ). The best results were obtained for derivatives 1 and 5 (Figure 1) with moderate $\mathrm{EC}_{50}$ values. Thus, compound 1 showed $\mathrm{EC}_{50}>14 \mu \mathrm{g} / \mathrm{mL}$ against HIV-1 (strain IIIB) and $\mathrm{EC}_{50}>12.4 \mu \mathrm{g} / \mathrm{mL}$ against HIV-2 (strain ROD), while the compound 5 showed $\mathrm{EC}_{50}>12.6 \mu \mathrm{g} / \mathrm{mL}$ against HIV-1 and $\mathrm{EC}_{50}>12.5 \mu \mathrm{g} / \mathrm{mL}$ against HIV-2. Low values for cytotoxicity concentration $50 \%$ (compound concentration that reduces the viability of mock-infected MT- 4 cells by $50 \%$ ), namely the $\mathrm{CC}_{50}$ value of $14.0 \pm 1.2 \mu \mathrm{g} / \mathrm{mL}$ for compound $\mathbf{1}$ and $13.3 \pm 0.8 \mu \mathrm{g} / \mathrm{mL}$ for compound 5 , respectively, resulted in low selectivity index $\mathrm{SI} \leq 1\left(\mathrm{SI}=\mathrm{CC}_{50} / \mathrm{EC}_{50}\right)$. Other derivatives showed lower activity with $\mathrm{EC}_{50}$ within the range of $47.4-125 \mu \mathrm{g} / \mathrm{mL}$. However, chemical modifications on this scaffold might lead to compounds with enhanced activity as NNRTIs [65].

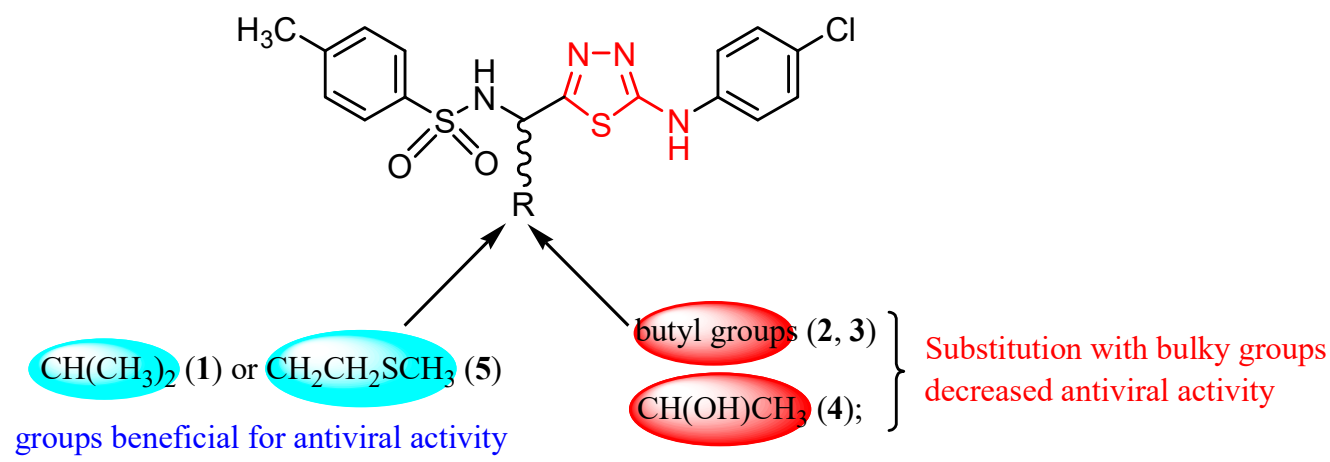

Figure 1. Influence of substituents of 1,3,4-thiadiazole derivatives $\mathbf{1 - 5}$ on anti-HIV activity.

Some 1,3,4-thiadiazole derivatives obtained by Hamad et al. [66] from amino acid analogs were screened for anti-HIV-1 (strain IIIB) and anti-HIV-2 (strain ROD) activity by the inhibition of the virus-induced cytopathic effect in human MT-4 cells based on 3-(4,5-dimethylthiazol-2-yl) -2,5-diphenyl tetrazolium bromide (MTT) assay. 2-(Naphthalen-2-yloxy)- $N$-((5-(phenylamino) -1,3,4-thiadiazol-2-yl)methyl)acetamide 6 showed in vitro inhibitory activity with $\mathrm{EC}_{50}$ values of $0.96 \mu \mathrm{g} / \mathrm{mL}$ (HIV-1 strain IIIB) and $2.92 \mu \mathrm{g} / \mathrm{mL}$ (HIV-2 strain ROD), respectively, but low selectivity $(\mathrm{SI}<1)$. Structure-activity relationship (SAR) studies have suggested that the substitution of the acetamide moiety with a thiadiazole ring may lead to more active derivatives compared to other compounds bearing different heterocyclic rings. Even though anti-HIV activity and selectivity of derivative 6 are limited compared to efavirenz $\left(\mathrm{EC}_{50}\right.$ value of $0.003 \mu \mathrm{g} / \mathrm{mL}$ and $\mathrm{SI} \approx 13333$ ), it may serve as the basis for future modification in the search for new potent non-nucleoside antiviral agents [66].<smiles>O=C(COc1ccc2ccccc2c1)NCc1nnc(Nc2ccccc2)s1</smiles> 
A new class of HIV-1 NNRTIs, N-aryl-2-arylthioacetamides, has been identified in the last years [67-70]. Studies on the crystalline structure of the RT-NNRTI complex suggested that NNRTIs have a common mode of action and interact with a hydrophobic pocket. $N$-aryl-2-arylthioacetamides adopted a butterfly-like conformation in which the arylthio moiety and the phenyl ring mimic the butterfly wings. SAR studies showed that the arylthio moiety strongly influenced the antiviral activity, leading to different results depending on the steric/electronic properties of the groups [47]. Based on these findings, Xiaohe et al. synthesized 2-(5-amino-1,3,4-thiadiazol-2-ylthio)-N-(aryl) acetamide derivatives 7-10 as new NNRTIs [47].<smiles>[R]C=C=C=[X]=C([X])NC(=O)CSc1nnc(N)s1</smiles>

Although they exhibited less anti-HIV-1 activity compared to standard drug zidovudine (half-maximal inhibitory concentration $\mathrm{IC}_{50}=0.016 \mu \mathrm{M}$ ), these compounds showed significant anti-HIV-1 activity at micromolar concentrations ( $\mathrm{IC}_{50}$ within the range of 7.50-20.83 $\left.\mu \mathrm{M}\right)$ (Table 1). It has been observed that the 2-amino-1,3,4-thiadiazole moiety may be a good group for anti-HIV-1 activity by providing promising antiviral agents. Moreover, the electronic properties of the $N$-aryl group influenced antiviral potency. The introduction of electron-withdrawing groups, such as fluorine or trifluoromethyl on phenyl ring (derivatives 8 and 9), enhanced antiviral activity compared to the unsubstituted phenyl derivative 7. SAR studies suggested that the steric/electronic properties of the $N$-phenyl substituents influenced the antiretroviral activity more than their positions. In addition, the nature of the $N$-aryl ring influenced the antiviral potency as can be observed for derivative $\mathbf{1 0}$ with a pyrimidyl ring which was the most active compound (Figure 2) [47].

Table 1. Structural details and $\mathrm{IC}_{50}$ values of compounds 7-10 (adapted from [47]).

\begin{tabular}{cccc}
\hline & $\mathbf{X}$ & $\mathbf{R}$ & $\mathbf{I C}_{\mathbf{5 0}}(\boldsymbol{\mu M})$ \\
\hline $\mathbf{7}$ & $\mathrm{CH}$ & $\mathrm{H}$ & $20.83 \pm 1.17$ \\
$\mathbf{8}$ & $\mathrm{CH}$ & $2,5-\mathrm{F}_{2}$ & $16.10 \pm 0.24$ \\
$\mathbf{9}$ & $\mathrm{CH}$ & $3,5-\left(\mathrm{CF}_{3}\right)_{2}$ & $14.93 \pm 0.84$ \\
$\mathbf{1 0}$ & $\mathrm{N}$ & $4,6-\left(\mathrm{OCH}_{3}\right)_{2}$ & $7.50 \pm 1.06$ \\
\hline
\end{tabular}

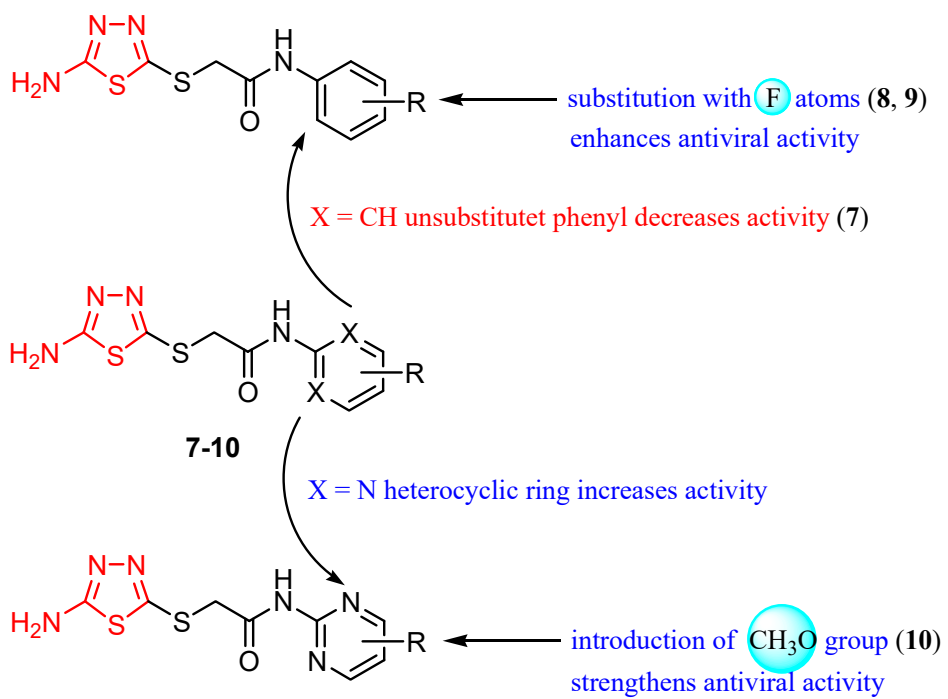

Figure 2. The influence of substituents of 1,3,4-thiadiazole derivatives 7-10 on anti-HIV activity. 
Molecular modeling studies for the pyrimidyl derivative $\mathbf{1 0}$ showed the formation of two potential intermolecular hydrogen bonds involving a nitrogen atom and the amino group of the thiadiazole ring and aminoacids from NNBS of RT. In addition, the electron-deficient pyrimidine ring of the ligand establishes $\pi-\pi$ interactions with the electron-rich benzene rings of RT. Despite the docking simulation results, the inhibitory activity of compound $\mathbf{1 0}$ against HIV-1 (strain IIIB) replication in MT-4 cell culture was lower than that of zidovudine. However, given the butterfly-like orientation as a necessary structural condition for antiretroviral activity, these results reveal the promising inhibitory potential of this scaffold [47].

The series of 5-(pyridin-2-ylmethyl)-1,3,4-thiadiazol-2-amine derivatives 11-16 were synthesized by intramolecular cyclization of the corresponding hydrazinecarbothioamides under acidic conditions and the activity against HIV-1 was tested on MT-4 cells by MTT assay using efavirenz as a standard drug [64].<smiles></smiles>

11-16

Except for derivative 11 which showed low activity $\left(\mathrm{EC}_{50}\right.$ values of $\left.47 \mu \mathrm{M}\right)$, the activity of the other compounds was even lower $\left(\mathrm{EC}_{50}\right.$ values $\left.>70 \mu \mathrm{M}\right)$ proving that substitution with halogens or halogenoalkyl groups at C3 and/or C4 of phenyl ring led to a decrease or loss of activity (Figure 3). Although pyridine derivatives did not exhibit selective anti-HIV-1 activity, the fact that compound 11 showed some antiviral activity may encourage further research on this structure. Subsequent chemical modifications by substitutions on aromatic rings with different groups may lead to compounds with improved activity [64].

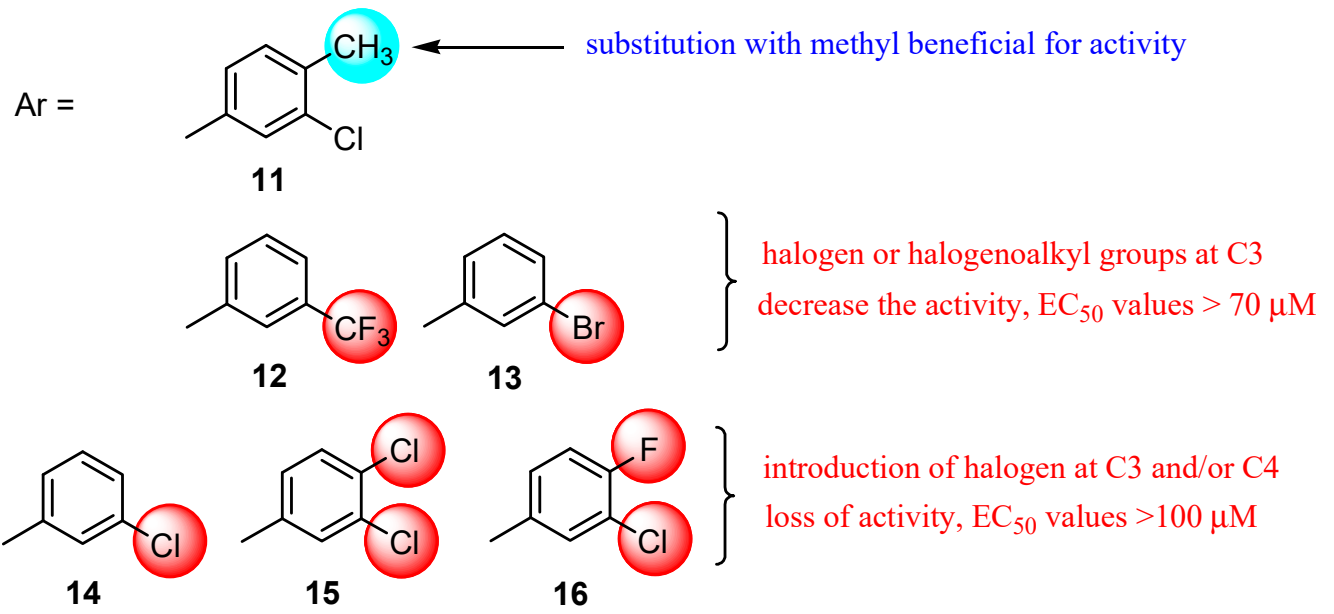

Figure 3. The influence of substituents of 1,3,4-thiadiazole derivatives 11-16 on anti-HIV activity.

The invasion of the central nervous system (CNS) by the HIV-1 virus frequently causes brain inflammation and progressive neurological diseases, which are commonly referred to as HIV associated neurocognitive disorders (HAND) [71]. HAND affects 7\%-15\% of AIDS patients and is characterized by neuronal dysfunction including synaptic damage, neuronal degeneration and cell dropout [72]. Cells involved in HAND pathogenesis are macrophages and microglia, which are the main targets of HIV-1 infection in the brain. When infected with HIV-1, macrophages and microglia increase the production and release of several soluble neurotoxic factors, such as glutamate, inducing neuronal damage [71].

Glutamine is the most abundant amino acid in the human body and is involved in more metabolic processes than any other amino acid. Glutamine is produced from glutamate and ammonia by the 
enzyme glutamine synthetase [73,74]. The conversion of glutamine to glutamate is catalyzed by the mitochondrial enzyme, glutaminase [72,75]. The glutamine/glutamate cycle in the human body plays several important metabolic functions. Thus, glutamine and glutamate are precursors to the biosynthesis of proteins, neurotransmitters, nucleotides, nucleic acids and other important biological molecules. The glutamine/glutamate cycle is the substrate for the synthesis of urea in the liver, genesis of ammonia in the kidneys and for hepatic and renal gluconeogenesis. The glutamine/glutamate exchange regulates the acid-base balance in kidneys, acts as an oxidative fuel for the intestines and cells of the immune system and provides the transport of nitrogen between organs [74-76]. The existence of a glutamine/glutamate cycle in CNS was confirmed in the last years [76,77]. Phosphate-activated mitochondrial glutaminase is the predominant enzyme that uses glutamine in the brain. Glutamine is present in the extracellular fluid of the brain at high concentrations and provides an abundant substrate for glutaminase [72,75]. Therefore, it has been hypothesized that mitochondrial glutaminase activation is responsible for the high levels of glutamate in the brains of HIV-1 infected patients [72]. While glutamate mediates different physiologic processes, elevated extracellular concentrations of glutamate can induce neuronal damage (e.g., dementia, brain atrophy) [71,72].

Some glutaminase inhibitors (e.g., 6-diazo-5-oxo-L-norleucine, etc.) were studied in vitro for their ability to prevent the generation of glutamate by HIV-1 infected macrophages. The results support the hypothesis that glutaminase mediates glutamate generation in HIV-infected human macrophages. When glutaminase was inhibited by various inhibitors, HIV-induced glutamate production decreased and the neuronal damage was diminished [71,72,78]. Furthermore, for some glutaminase inhibitors, a non-competitive mechanism of inhibition has been described [78]. These findings support glutaminase as a potential component of the HAND process and can provide a new therapeutic target for the treatment of neurocognitive disorders associated with HIV infection [71,72,78]. In connection with these results, a large number of glutaminase inhibitors having a bis-thiadiazole (17) and a pyridazine-thiadiazole (18) skeleton (Figure 4), respectively, were synthesized as a method of treating or preventing multiple viral infections, including infections with retroviruses [75].<smiles>[Y]Nc1nnc(C([R2])[X])s1</smiles>

17<smiles>[Y]Nc1nnc(C([R])[X])s1</smiles>

18

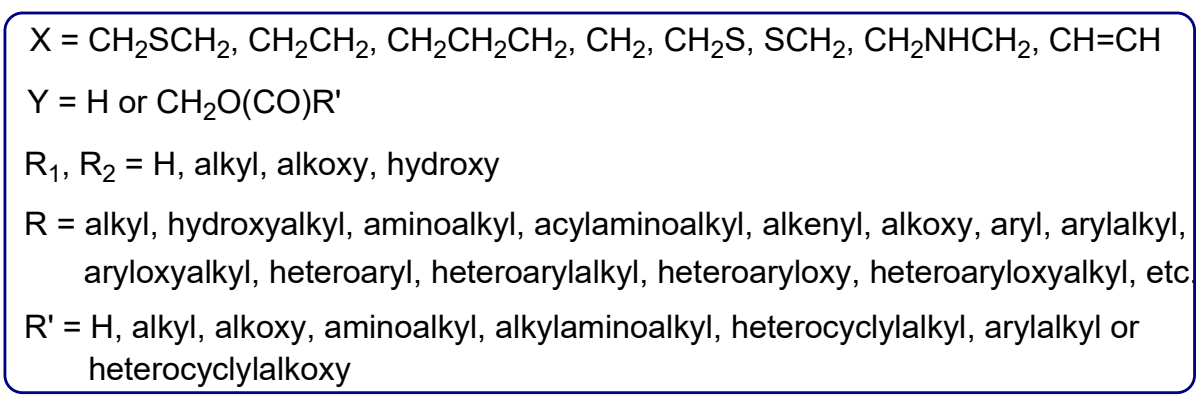

Figure 4. The general formula of glutaminase inhibitors $\mathbf{1 7}$ and $\mathbf{1 8 .}$

Multiple experiments were performed in order to study the biological profile of the compounds. Some of the synthesized derivatives are prodrugs, which under physiologic conditions (in vivo), are converted into the therapeutically active parent compound. Studies have also been conducted to obtain pharmaceutical preparations suitable for use in human patients comprising any of the synthesized derivatives and one or more pharmaceutically acceptable excipients. In addition, the authors assume that the derivatives may be used alone or in combination with known antiviral drugs. Studies on 
kidney-type glutaminase inhibition showed good results for many derivatives such as compound 19 with an $\mathrm{IC}_{50}$ value of $0.24 \mu \mathrm{M}$ and its deuterium derivative 20 with an $\mathrm{IC}_{50}$ value of $0.54 \mu \mathrm{M}$ [75].<smiles>COc1cccc(CC(=O)Nc2ccc(CCCCc3nnc(N)s3)nn2)c1</smiles>

19<smiles>[2H]C([2H])(CCc1nnc(N)s1)C([2H])([2H])c1ccc(NC(=O)Cc2cccc(OC(F)(F)F)c2)nn1</smiles>

20

\subsection{Human Cytomegalovirus (HCMV)}

Human cytomegalovirus (HCMV, Herpesviridae family) is a ubiquitous deoxyribonucleic acid virus that infects people of all ages $[79,80]$. HCMV infection can be acquired through horizontal and vertical transmission. HCMV spreads from infected people through direct contact with body fluids that carry the virus, such as urine, saliva, cervicovaginal secretions, sperm and breast milk. Vertical transmission through organ transplantation, from mother to child or transmission via blood transfusion, is also possible $[79,80]$. Blood tests indicate that $60 \%-90 \%$ of the adult population experienced HCMV infection at some time during their life [81]. Although most of these infections are asymptomatic, certain patient groups such as babies that are infected before birth and children or adults with weakened immune systems due to diseases or medications (e.g., HIV-infected patients, organ transplant recipients) can develop severe illnesses that require medical treatment [79]. HCMV is able to remain latent in several cells of the human body for a long time and can be reactivated if the person develops immune system suppression $[79,82]$.

The first-line drugs recommended for the treatment of HCMV infection are intravenous ganciclovir or orally administered valganciclovir [83]. Although tolerability of ganciclovir and valganciclovir is acceptable, hematological or neurological side effects can occur. Neutropenia, thrombocytopenia and anemia are the main toxic effects that limit therapy with these drugs. Serum creatinine levels may increase during ganciclovir therapy, which requires monitoring of renal function [84]. Encephalopathy is the neurotoxic effect of ganciclovir and valganciclovir [85]. Foscarnet is also a very effective anti-HCMV drug, and cidofovir is a broad-spectrum antiviral with good activity against HCMV. Both drugs cause a high level of nephrotoxicity that limits treatment [83].

Novel 2-amino-1,3,4-thiadiazole derivatives with antiviral activity against HCMV have been patented [86]. A large number of 472 synthesized compounds were tested in an HCMV polymerase assay at a concentration of $25 \mu \mathrm{M}$. The degree of enzyme inhibition ranged from $20 \%$ to $100 \%$. Among the most active compounds, four derivatives exhibited a 100\% inhibition rate, 29 derivatives showed an inhibition rate of $90.1 \%-99.9 \%$ and 16 derivatives showed an inhibition rate of $80.3 \%-89.9 \%$. Three structural series stand out among the most active 1,3,4-thiadiazole derivatives: 1,3-dioxo-1,3-dihydro-2-benzofuran-5-carboxamide derivatives such as 21-30, 9-octadecenamide derivatives such as 31-38 and 2-ethoxy-1-naphthamide derivatives such as 39-42 (Tables 2-4). Most of the derivatives belong to the 1,3-dioxo-1,3-dihydro-2-benzofuran-5-carboxamide series. At the same time, the most active compounds belong to this series, so it can be concluded that the 1,3-dioxo-1,3-dihydro-2-benzofuran-5-carboxamide moiety is a good scaffold for anti-HCMV activity [86].<smiles>[R]Nc1nnc(NC(=O)c2ccc3c(c2)C(=O)OC3=O)s1</smiles>

21-30<smiles>[R]Nc1nnc(NC(=O)CCCCCCCCCCCCCCCCCC)s1</smiles>

31-38<smiles>[R]Nc1nnc(NC(=O)c2cc3ccccc3cc2OCC)s1</smiles>

$39-42$ 
Table 2. Structural details and human cytomegalovirus (HCMV) polymerase inhibition values of compounds 21-30 (adapted from [86]).

Inhibition (\%) Inhibition (\%)

Table 3. Structural details and HCMV polymerase inhibition values of compounds 31-38 (adapted from [86]).

Inhibition (\%)

Table 4. Structural details and HCMV polymerase inhibition values of compounds 39-42 (adapted from [86]).

Inhibition (\%)


Other compounds also showed good inhibitory activity. These derivatives contain a five- to six-membered saturated heterocyclic moiety, such as imidazolidinyl, tetrahydrofuryl, piperidinyl, morpholinyl, thiomorpholinyl or 5- to 10-membered aromatic or unsaturated heterocyclic moiety such as furyl, pyrrolyl, pyridyl, benzothiazolyl, etc. (e.g., derivatives 43,44 ) [86].

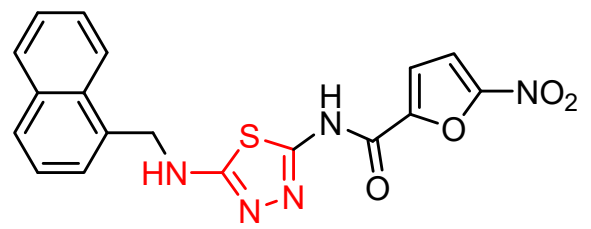

43 (83.3\% inhibition)

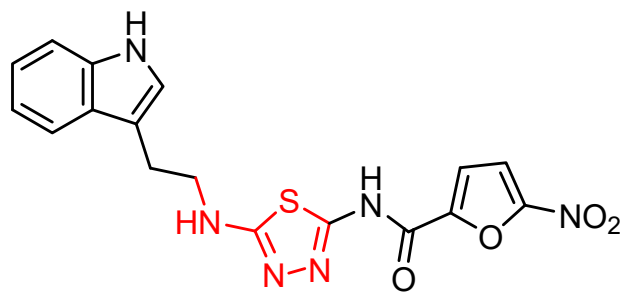

44 (81.6\% inhibition)

While the synthesized derivatives have shown inhibitory activity against HCMV polymerase, their antiviral activity cannot be limited to a specific mechanism of action. These compounds may be active against cytomegalovirus by HCMV polymerase inhibition or by other mechanisms of action. In addition, during the experiments, many of these compounds also showed activity against other herpes viruses, such as varicella-zoster virus (VZV), Epstein-Barr virus (EBV), herpes simplex virus (HSV), and human herpesvirus type 8 (HHV-8). Pharmaceutical compositions containing such compounds or their pharmaceutically acceptable salts useful as antiviral agents have also been studied. Studies have been conducted for the administration of pharmaceutical preparations by parenteral, topical, oral or rectal route, depending on the purpose of their use to treat internal or external viral infections [86].

\subsection{Respiratory Viruses}

Acute respiratory infections are a major global health problem responsible for about 3.9 million deaths worldwide each year $[87,88]$. These infections are of the top five causes of mortality worldwide and the leading cause of mortality among children under five years of age in many developing countries [87,89]. Acute respiratory infections are most often caused by viruses. Over 200 viral serotypes are associated with human respiratory diseases [90] including Influenza A and Influenza B virus, respiratory syncytial virus (RSV), parainfluenza virus (PIV), human adenovirus (HAdV), human coronavirus (HCoV), human rhinovirus (HRV), human metapneumovirus (HMPV) and human bocavirus (HBoV). In addition, two human polyomaviruses (HPyV), KIPyV and WUPyV, have been detected in patients with respiratory infections [91]. These infections affect all age groups, but nearly all severe episodes occur in children under five years, the elderly and immunocompromised individuals (e.g., HIV-infected patients) [87,89]. In adults, viral respiratory infections are the cause of 30\%-50\% of pneumonia cases, $80 \%$ of asthma complications and $20 \%-60 \%$ of chronic obstructive pulmonary disease exacerbations [87]. Consequently, common viral respiratory infections cause a greater economic burden than many other clinical conditions in terms of medical expenses and productivity losses [87,92]. The World Health Organization has supported the monitoring of acute respiratory diseases worldwide since 1977 [91].

The Influenza virus belongs to the Orthomyxoviridae family and causes respiratory infections in about $20 \%$ of the global population every year. The 1918 flu pandemic was caused by Influenza A subtype H1N1 and killed 50 million people around the world [93]. The Asian Influenza caused by Influenza A subtype H2N2 occurred in 1957 and the Hong Kong Influenza caused by Influenza A subtype H3N2 took place in 1968 and made far fewer victims than the 1918 Spanish flu. About 70 people died in Asia in 2004-2005 due to the H5N1 strain of avian flu [93]. The 2009 flu pandemic (swine flu) was the second pandemic involving a strain of Influenza A virus. It was classified as Influenza A H1N1 2009 and the genetic material originated from three different species: human, avian and swine [7,94]. 
The chemotherapy or prophylaxis of Influenza infections comprises agents blocking the Influenza A virus M2 proton-selective ion channel (amantadine, rimantadine) and neuraminidase inhibitors (zanamivir, oseltamivir, laninamivir, peramivir) [1,93]. Both classes can induce virus resistance and therefore there is an urgent need to develop new antiviral agents with novel mechanisms of action. An alternative concept has recently emerged and it is based on the idea of designing new molecules targeting host cell factors that are hijacked by the virus during its replication. Host-targeting antivirals are an alternative strategy for addressing host structures involved in the virus life cycle. This type of inhibitors could exhibit a significantly greater barrier for selecting drug-resistant viruses and, in addition, display broad-spectrum antiviral activity when interacting with a cellular target common to several viruses. The host factor-directed antiviral therapy is recently studied. This is increasingly recognized as a relevant approach to combat viral resistance and provides broad-spectrum antiviral agents $[95,96]$.

Many studies are currently being developed to find new Influenza inhibitors. Tatar et al. synthesized 2-phenylamino-1,3,4-thiadiazole derivatives 45-48 [49].<smiles>CSCCC(NC(=O)c1ccccc1)c1nnc(Nc2ccccc2)s1</smiles>

45<smiles>CSCCC(N)c1nnc(Nc2ccccc2)s1</smiles>

46<smiles>[R]c1cccc(NC(=S)NC(CCSC)c2nnc(Nc3ccccc3)s2)c1</smiles>

$47 \mathrm{R}=4-\mathrm{CN}$

$48 \mathrm{R}=3-\mathrm{CF}_{3}, 4-\mathrm{Cl}$

The antiviral activity against some respiratory viruses such as Influenza A H1N1, Influenza A H3N2, Influenza B, Parainfluenza-3, RSV, Reovirus-1and Feline Coronavirus was investigated and the results are summarized in Table 5 . No activity was observed at the highest concentration tested or at subtoxic concentration against Influenza B and RSV [49].

Table 5. Antiviral evaluation and in vitro cytotoxicity of compounds 45-48 (adapted from [49]).

\begin{tabular}{|c|c|c|c|c|c|c|c|c|c|c|}
\hline & \multicolumn{2}{|c|}{$\begin{array}{c}\text { Influenza A } \\
\text { H1N1 }\end{array}$} & \multicolumn{2}{|c|}{$\begin{array}{c}\text { Influenza A } \\
\text { H3N2 }\end{array}$} & \multicolumn{2}{|c|}{ Para Influenza-3 } & \multicolumn{2}{|c|}{ Reovirus-1 } & \multicolumn{2}{|c|}{$\begin{array}{c}\text { Feline } \\
\text { Coronavirus }\end{array}$} \\
\hline & $\begin{array}{l}\mathrm{EC}_{50} \\
(\mu \mathrm{M})\end{array}$ & $\begin{array}{l}\mathrm{CC}_{50} \\
(\mu \mathrm{M})\end{array}$ & $\begin{array}{l}\mathrm{EC}_{50} \\
(\mu \mathrm{M})\end{array}$ & $\begin{array}{l}\mathrm{CC}_{50} \\
(\mu \mathrm{M})\end{array}$ & $\begin{array}{l}\mathrm{EC}_{50} \\
(\mu \mathrm{M})\end{array}$ & $\begin{array}{l}\text { MCC } \\
(\mu \mathrm{M})\end{array}$ & $\begin{array}{l}\mathrm{EC}_{50} \\
(\mu \mathrm{M})\end{array}$ & $\begin{array}{l}\text { MCC } \\
(\mu \mathrm{M})\end{array}$ & $\begin{array}{l}\mathrm{EC}_{50} \\
(\mu \mathrm{M})\end{array}$ & $\begin{array}{l}\mathrm{CC}_{50} \\
(\mu \mathrm{M})\end{array}$ \\
\hline 45 & 42 & $>100$ & 31.4 & $>100$ & $>20$ & $\geq 20$ & $>20$ & $\geq 20$ & $>100$ & $>100$ \\
\hline 46 & - & 23 & - & 23 & $>100$ & $>100$ & $>100$ & $>100$ & $>100$ & $>100$ \\
\hline 47 & - & 79 & - & 79 & $>20$ & 100 & $>20$ & 100 & $>100$ & $>100$ \\
\hline 48 & - & 2.7 & - & 2.7 & $>4$ & 20 & $>4$ & 20 & $>4$ & 11 \\
\hline $\begin{array}{l}\text { Oseltamivir } \\
\text { carboxylate }\end{array}$ & 4.7 & $>100$ & 9 & $>100$ & - & - & - & - & - & - \\
\hline Ribavirine & 8 & $>100$ & 8.1 & $>100$ & 50 & $>250$ & $>250$ & $>250$ & - & - \\
\hline Amantadine & 127 & $>500$ & 1.7 & $>500$ & - & - & - & - & - & - \\
\hline
\end{tabular}

The in vitro antiviral assay showed $N$-\{3-(methylthio)-1-[5-(phenylamino)-1,3,4-thiadiazol-2-yl]propyl $\}$ benzamide 45 as an Influenza $\mathrm{A}_{3} \mathrm{~N}_{2}$ virus subtype inhibitor. With an $\mathrm{EC}_{50}$ value of $31.4 \mu \mathrm{M}$, the derivative $\mathbf{4 5}$ was the most potent among the tested compounds and moderate active compared to standard drug oseltamivir, but a promising scaffold for future developments. Derivatives $\mathbf{4 7}$ and $\mathbf{4 8}$ exhibited activity against Parainfluenza- 3 and Reovirus- 1 and probably the thiourea moiety favors antiviral activity on these strains (Figure 5) [49]. 


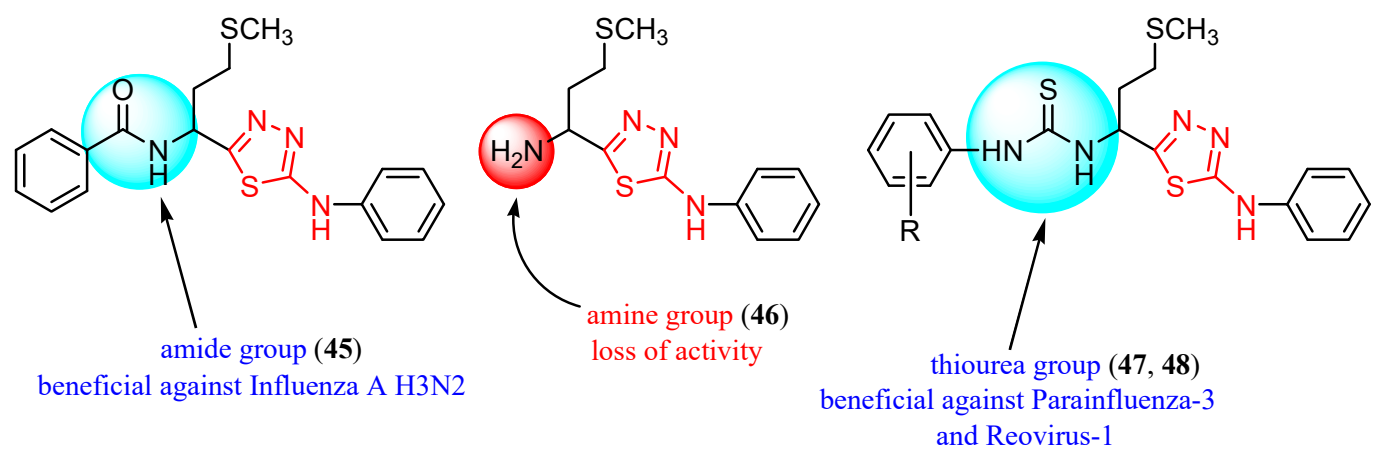

Figure 5. The influence of substituents of 1,3,4-thiadiazole derivatives 45-48 on anti-respiratory viruses' activity.

\subsection{Hepatitis Viruses}

Viral hepatitis is a liver inflammation responsible for about 171,000 deaths every year in the European Region. Patients may have an acute form as a recent infection, with relatively rapid onset or a chronic form. There are five main hepatitis viruses (HAV, HBV, HCV, HDV and HEV) with different ways of transmission and different impact on human health [97]. While HAV or HEV infection is usually mild, with most people recovering quickly and completely, infection with HBV, HCV or HDV often leads to chronic infections and progressive liver damage with the development of cirrhosis and liver cancer [97]. There are about 15 million people living with chronic HBV infection and about 14 million with HCV infection in the European Region [97]. Safe and effective vaccines for the prevention of HBV infection have been available since the 1990s. These vaccines also provide protection from HDV infection. Unfortunately, the HCV vaccine has not yet been developed $[97,98]$. Many patients infected with HBV are adults born before the hepatitis B vaccine became available in the 1990s. In these cases, drug treatment is the only option [98]. Several nucleoside and non-nucleoside derivatives with anti-HBV (e.g., adefovir, entecavir, lamivudine, telbivudine, tenofovir) or anti-HCV activity (e.g., boceprevir, grazoprevir, elbasvir, ledipasvir, sofosbuvir, telaprevir) are in use $[3,99]$ and chronic infections with HBV and HCV can be currently controlled or even cured. Due to the costs of antiviral drugs for chronic hepatitis, access to treatment is a major obstacle in many countries and finding new, less expensive antiviral drugs is a necessity [97].

1,2-Dihydro-4,6-dimethyl-2-oxo-1-[(5-(phenylamino)-1,3,4-thiadiazol-2-yl)methyl]pyridine-3carbonitrile 49 was prepared from the corresponding phehylthiosemicarbazide by cyclization in sulfuric acid [6]. The derivative $\mathbf{4 9}$ was tested for antiviral activity against the hepatitis B virus (HBV) using HepG2.2.2.15 cell line, a human hepatoblastoma cell line that produces HBV viral particles. Cytotoxicity was also tested by the cell viability method (MTT assay). Preliminary screening indicated high inhibitory activity against $\mathrm{HBV}$ with an $\mathrm{IC}_{50}$ value of $0.3 \mu \mathrm{M}$, low cytotoxicity $\left(\mathrm{CC}_{50}\right.$ value of $333.3 \mu \mathrm{M})$ and a selectivity index SI of 1111 compared to the standard drug lamivudine $\left(\mathrm{IC}_{50}\right.$ value of $0.1 \mu \mathrm{M})$. From these results, it can be concluded that pyridine-2-one may be a good substituent on the 1,3,4-thiadiazole ring, and these two moieties together make a promising scaffold in promoting anti-HBV activity [6].<smiles>Cc1cc(C)n(Cc2nnc(Nc3ccccc3)s2)c(=O)c1C#N</smiles> 


\subsection{Miscellaneous Viruses}

Sindbis fever, a less common human viral disease, is caused by a mosquito-borne virus called Sindbis virus (Togaviridae family). Despite the wide distribution of Sindbis virus, symptomatic infections in humans have been reported in only a few limited geographical areas such as northern Europe (Finland, Sweden and Russia), South Africa, Australia and China [100]. 1,3,4-Thiadiazole derivatives 50-55 were tested for antiviral activity against several viruses [101].

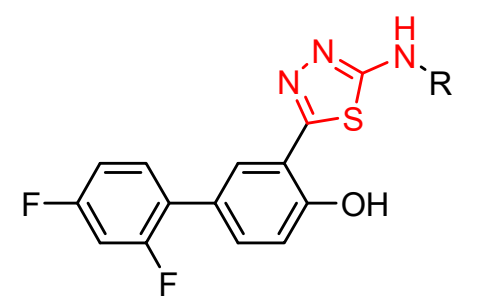

$$
\begin{aligned}
\mathrm{R}= & \mathrm{CH}_{3}(50) ; \mathrm{CH}_{2} \mathrm{CH}=\mathrm{CH}_{2}(51) ; \mathrm{C}_{6} \mathrm{H}_{5}(52) \\
& \mathrm{C}_{6} \mathrm{H}_{4} \mathrm{CH}_{3}(\mathrm{p})(53) ; \mathrm{C}_{6} \mathrm{H}_{4} \mathrm{OCH}_{3}(\mathrm{p})(54) ; \mathrm{C}_{6} \mathrm{H}_{11}(55
\end{aligned}
$$

The derivatives $\mathbf{5 0}$ (methyl) and $\mathbf{5 1}$ (allyl) showed antiviral activity against herpes simplex virus-1 TK-KOS and herpes simplex virus-1 TK-KOS ACV, Sindbis virus, Coxsackie virus B4 and Punto Toro virus at a concentration of $16 \mu \mathrm{g} / \mathrm{mL}$. The highest antiviral activity was exhibited against Sindbis virus by derivative 50 at a concentration of $9.6 \mu \mathrm{g} / \mathrm{mL}$. It seems that the size of the amino group substituent influenced the antiviral activity. While derivatives $\mathbf{5 0}$ and $\mathbf{5 1}$ with small alkyl groups showed antiviral activity, compounds with bulky aromatic (52,53 and 54) or cycloalkyl (55) groups were not capable of viral inhibition (Figure 6) [101].

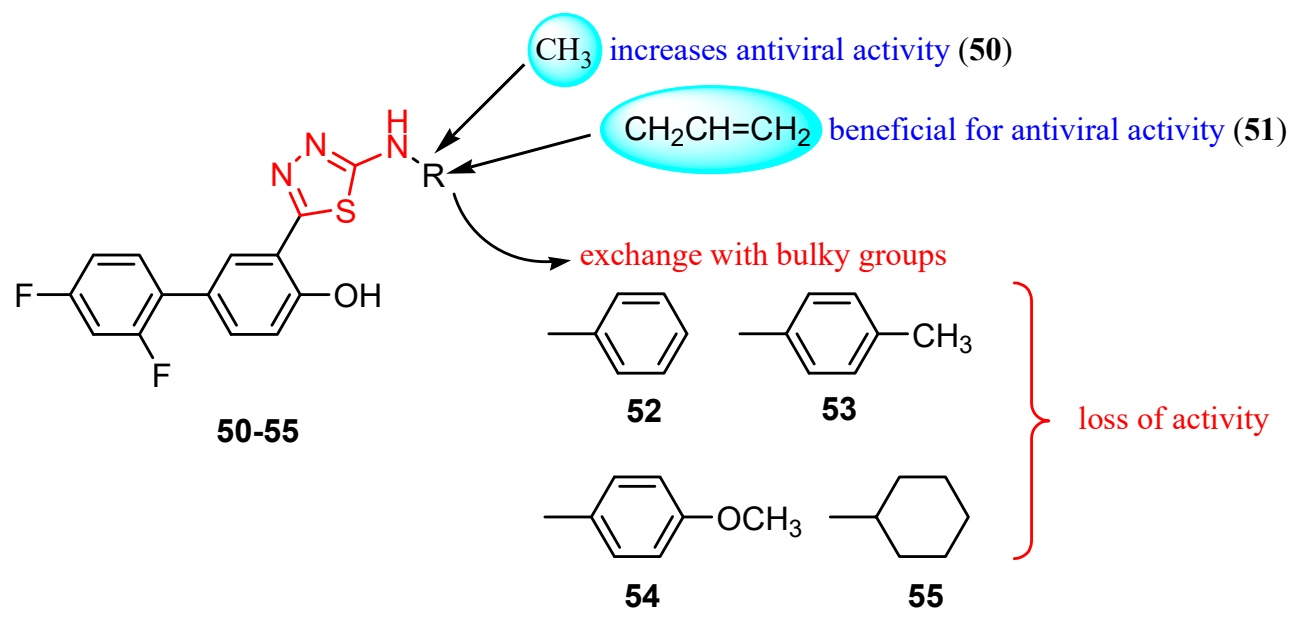

Figure 6. The influence of substituents of 1,3,4-thiadiazole derivatives $\mathbf{5 0 - 5 5}$ on viral inhibition.

2-Phenylamino-1,3,4-thiadiazole derivatives 45-48 were also screened against herpes simplex HSV-1 and HSV-2, herpes simplex virus-1 TK-KOS ACV, Sindbis virus, Coxsackie virus B4 and Punto Toro virus (Table 6) [49]. While amide $\mathbf{4 5}$ and amine $\mathbf{4 6}$ did not exhibit antiviral activity at subtoxic concentrations, in vitro tests showed antiviral activity for thiourea derivatives 47 and 48, highlighting what other studies have reported that derivatives bearing the-NH-CS-NH- group have demonstrated antiviral activity. Derivative $\mathbf{4 8}$ exhibited activity against different strains of HSV and both derivatives 47 and 48 showed activity against Sindbis virus, Coxsackie virus B4 and Punto Toro virus (Figure 7) [49]. 
Table 6. Antiviral evaluation and in vitro cytotoxicity of compounds 45-48 (adapted from [49]).

\begin{tabular}{|c|c|c|c|c|c|c|c|c|c|c|c|c|}
\hline & \multicolumn{2}{|c|}{ HSV-1 } & \multicolumn{2}{|c|}{ HSV-2 } & \multicolumn{2}{|c|}{$\begin{array}{c}\text { HSV-1 } \\
\text { (TK-KOS } \\
\text { ACV) }\end{array}$} & \multicolumn{2}{|c|}{$\begin{array}{l}\text { Sindbis } \\
\text { Virus }\end{array}$} & \multicolumn{2}{|c|}{$\begin{array}{c}\text { Coxsackie } \\
\text { Virus B4 }\end{array}$} & \multicolumn{2}{|c|}{$\begin{array}{l}\text { Punto Toro } \\
\text { Virus }\end{array}$} \\
\hline & $\begin{array}{l}\mathrm{EC}_{50} \\
(\mu \mathrm{M})\end{array}$ & $\begin{array}{l}\text { MCC } \\
(\mu \mathrm{M})\end{array}$ & $\begin{array}{l}\mathrm{EC}_{50} \\
(\mu \mathrm{M})\end{array}$ & $\begin{array}{l}\text { MCC } \\
(\mu \mathrm{M})\end{array}$ & $\begin{array}{l}\mathrm{EC}_{50} \\
(\mu \mathrm{M})\end{array}$ & $\begin{array}{l}\text { MCC } \\
(\mu \mathrm{M})\end{array}$ & $\begin{array}{l}\mathrm{EC}_{50} \\
(\mu \mathrm{M})\end{array}$ & $\begin{array}{l}\text { MCC } \\
(\mu \mathrm{M})\end{array}$ & $\begin{array}{l}\mathrm{EC}_{50} \\
(\mu \mathrm{M})\end{array}$ & $\begin{array}{l}\text { MCC } \\
(\mu \mathrm{M})\end{array}$ & $\begin{array}{l}\mathrm{EC}_{50} \\
(\mu \mathrm{M})\end{array}$ & $\begin{array}{l}\text { MCC } \\
(\mu \mathrm{M})\end{array}$ \\
\hline 45 & $>20$ & $\geq 20$ & $>20$ & $\geq 20$ & $>20$ & $\geq 20$ & $>20$ & $\geq 20$ & $>20$ & $\geq 20$ & $>20$ & $\geq 20$ \\
\hline 46 & $>100$ & $>100$ & $>100$ & $>100$ & $>100$ & $>100$ & $>100$ & $>100$ & $>100$ & $>100$ & $>100$ & $>100$ \\
\hline 47 & $>100$ & $>100$ & $>100$ & $>100$ & $>100$ & $>100$ & $>20$ & 100 & $>20$ & 100 & $>20$ & 100 \\
\hline 48 & $>20$ & 100 & $>20$ & 100 & $>20$ & 100 & $>4$ & 20 & $>4$ & 20 & $>4$ & 20 \\
\hline Acyclovir & 0.9 & $>250$ & 0.4 & $>250$ & $>250$ & $>250$ & - & - & - & - & - & - \\
\hline Ribavirine & - & - & - & - & - & - & $>250$ & $>250$ & $>250$ & $>250$ & 112 & $>250$ \\
\hline
\end{tabular}

MCC: minimum cytotoxic concentration.
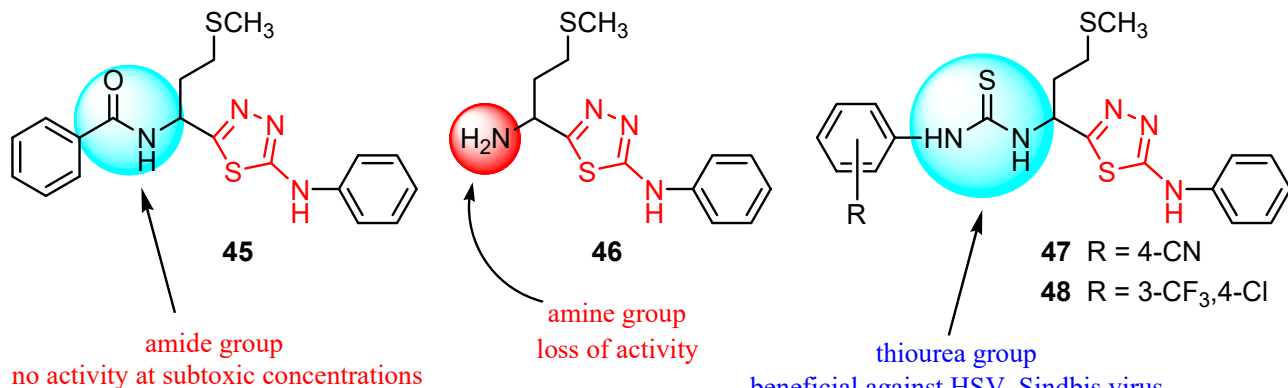

beneficial against HSV, Sindbis virus,

Coxsackie virus, Punto Toro virus

Figure 7. The influence of substituents of 1,3,4-thiadiazole derivatives $\mathbf{4 5 - 4 8}$ on antiviral activity.

2-Amino-5-(2-sulphamoylphenyl)-1,3,4-thiadiazole 56 reduced the replication of some DNA viruses such as adenovirus Ad17 and herpes simplex HSV-1 and RNA viruses such as Poliovirus 1, Echovirus 2 and Coxsackie virus B4 at concentrations ranging from 20 to $100 \mu \mathrm{g} / \mathrm{mL}[102,103]$. In vitro experiments were performed using samples of $10^{6}$ human aneuploid HEp-2 cells that were infected with 10 infectious units per cell. Derivative $\mathbf{5 6}$ was highly active against all viral strains, significantly reducing viral replication at a concentration of $50 \mu \mathrm{g} / \mathrm{mL}$. The best inhibition was recorded against Echovirus 2 virions that were completely inhibited at a concentration of $20 \mu \mathrm{g} / \mathrm{mL}$ (Table 7). Regarding the mechanism of action, the authors assume that compound $\mathbf{5 6}$ may act on the viral structural proteins preventing the assembly of virus particles [102].

Derivatives of compound 56 were prepared. Methyl derivative 57 and allyl derivative 58 reduced the replication of RNA viruses (Poliovirus 1 and Coxsackie virus B4) at concentrations of 50 and $100 \mu \mathrm{g} / \mathrm{mL}$, while ethyl derivative 59 was completely inactive against all viral strains (Table 7). These results suggest the importance of the side chain for antiviral activity (Figure 8) [102].

$$
\mathrm{R}=\mathrm{H}(\mathbf{5 6}) ; \mathrm{CH}_{3}(\mathbf{5 7}) ; \mathrm{CH}_{2} \mathrm{CH}=\mathrm{CH}_{2}(\mathbf{5 8}) ; \mathrm{C}_{2} \mathrm{H}_{5}(\mathbf{5 9})
$$


Table 7. Antiviral evaluation and in vitro cytotoxicity of compounds 56-59 (adapted from [102]).

\begin{tabular}{|c|c|c|c|c|c|c|c|}
\hline & $\begin{array}{l}\text { Concn } \\
(\mu \mathrm{g} / \mathrm{mL})\end{array}$ & $\begin{array}{c}\text { Ad17 } \\
\text { (Cells } \\
\text { Number) }\end{array}$ & $\begin{array}{c}\text { HSV-1 } \\
\text { (Cells } \\
\text { Number) }\end{array}$ & $\begin{array}{l}\text { Poliovirus } \\
1 \text { (Cells } \\
\text { Number) }\end{array}$ & $\begin{array}{l}\text { Echovirus } \\
2 \text { (Cells } \\
\text { Number) }\end{array}$ & $\begin{array}{c}\text { Coxsackie virus } \\
\text { B4 (Cells } \\
\text { Number) }\end{array}$ & $\begin{array}{c}\text { MNC } \\
(\mu \mathrm{g} / \mathrm{mL})\end{array}$ \\
\hline blank & & $5 \times 10^{8}$ & $3 \times 10^{6}$ & $3 \times 10^{9}$ & $2 \times 10^{9}$ & $3 \times 10^{8}$ & \\
\hline \multirow{3}{*}{56} & 20 & $7 \times 10^{6}$ & $6 \times 10^{5}$ & $4 \times 10^{6}$ & 0 & $6 \times 10^{5}$ & \multirow{3}{*}{900} \\
\hline & 50 & $4 \times 10^{2}$ & $5 \times 10^{4}$ & $2 \times 10^{3}$ & 0 & $2 \times 10^{3}$ & \\
\hline & 100 & $2 \times 10^{2}$ & $3 \times 10^{4}$ & $1 \times 10^{3}$ & 0 & $2 \times 10^{3}$ & \\
\hline \multirow{2}{*}{57} & 50 & $6 \times 10^{8}$ & $3 \times 10^{6}$ & $2 \times 10^{5}$ & - & $8 \times 10^{4}$ & \multirow{2}{*}{800} \\
\hline & 100 & $6 \times 10^{8}$ & $2 \times 10^{6}$ & $8 \times 10^{4}$ & - & $2 \times 10^{4}$ & \\
\hline \multirow{2}{*}{58} & 50 & $4 \times 10^{8}$ & $2 \times 10^{6}$ & $3 \times 10^{4}$ & - & $2 \times 10^{4}$ & \multirow{2}{*}{800} \\
\hline & 100 & $5 \times 10^{8}$ & $3 \times 10^{6}$ & $2 \times 10^{4}$ & - & $2 \times 10^{4}$ & \\
\hline \multirow{2}{*}{59} & 50 & $4 \times 10^{8}$ & $2 \times 10^{6}$ & $3 \times 10^{9}$ & $2 \times 10^{9}$ & $3 \times 10^{8}$ & \multirow{2}{*}{1300} \\
\hline & 100 & $5 \times 10^{8}$ & $3 \times 10^{6}$ & $3 \times 10^{9}$ & $2 \times 10^{9}$ & $3 \times 10^{8}$ & \\
\hline
\end{tabular}

Concn: concentration; MNC: maximum noncytotoxic concentration.

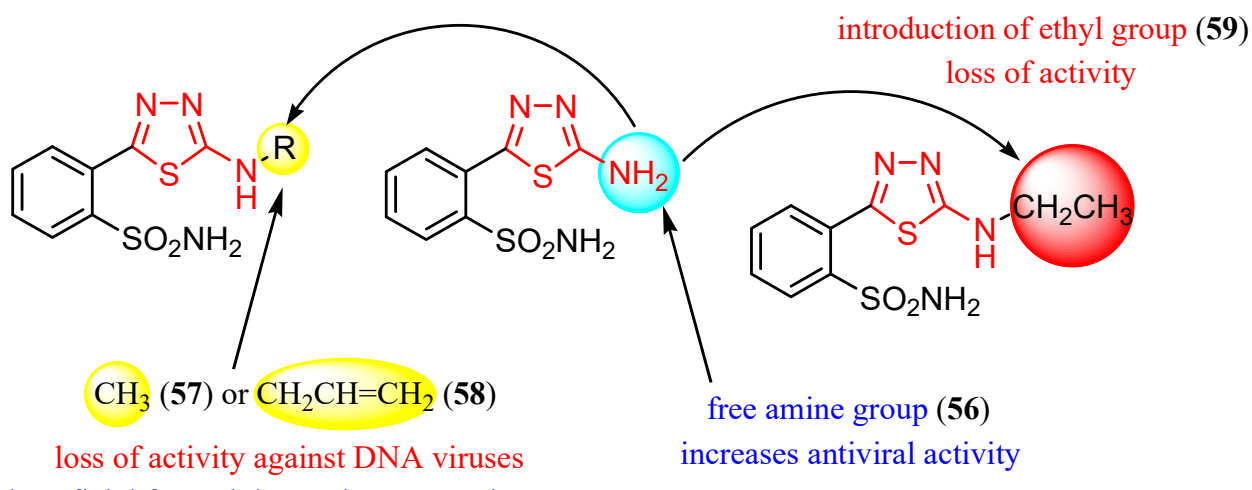

beneficial for activity against RNA viruses

Figure 8. The influence of substituents of 1,3,4-thiadiazole derivatives 56-59 on antiviral activity.

Cui et al. synthesized several pyrrolyl-1,3,4-thiadiazoles with general formula 60 (Figure 9). The compounds showed antiviral activity against some viruses of the Flaviviridae family such as West Nile virus and dengue virus [25,104].<smiles>[R]c1ccc(CNc2nnc(-n3c([X])c([Y])c(C(=O)c4cc5ccccc5o4)c3-c3ccc(Cl)c(Cl)c3)s2)cc1</smiles>

60

$\mathrm{X}=\mathrm{O}, \mathrm{S}, \mathrm{NH} ; \mathrm{Y}=\mathrm{OH}, \mathrm{SH} ; \mathrm{R}=\mathrm{H}, \mathrm{OH}, \mathrm{CN}$, halo, alkyl, alkoxy

Figure 9. The general formula of derivatives 60.

The use of non-nucleoside derivatives as antiviral chemotherapeutic agents has stimulated extensive research into the synthesis of compounds of this class. However, many antiviral drugs are nucleoside analogs that act by suppressing the synthesis of viral DNA or RNA which leads to inhibition of virus replication or cell division. Research has been carried out to find new nucleoside antiviral agents in which the natural nucleobases have been replaced by heterocyclic rings, as can be seen in derivatives 61-64 [105]. 


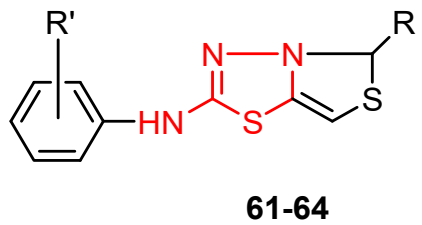

The antiviral activity was evaluated in vitro against viral strains parasitizing Chenopodium amaranticolor. The ability of derivatives 61-64 to control the viral infection of Chenopodium amaranticolor leaves was studied at two concentrations: $1000 \mathrm{ppm}$ and $100 \mathrm{ppm}$. Generally, the compounds showed good rates of viral infection control at $1000 \mathrm{ppm}$. The best results were observed for the derivatives bearing the D-xylobutyl group (compound $62-82 \%$ control and derivative $64-76 \%$ control). The substituent on the aryl ring did not significantly influence biological activity, although the compounds $\mathbf{6 1}$ and $\mathbf{6 2}$ having a methoxy group were slightly more active than derivatives $\mathbf{6 3}$ and 64 bearing a methyl group (Table 8, Figure 10). The study may be useful in obtaining new pesticides for agriculture [105].

Table 8. Structural details and antiviral activity of compounds 61-64 (adapted from [105]).

\begin{tabular}{ccccc}
\hline & \multirow{2}{*}{$\mathbf{R}^{\prime}$} & $\mathbf{R}$ & \multicolumn{2}{c}{ Viral Infection Control (\%) } \\
\cline { 3 - 5 } & & & $\mathbf{1 0 0 0} \mathbf{~ p p m}$ & $\mathbf{1 0 0} \mathbf{~ p p m}$ \\
\hline $\mathbf{6 1}$ & $4-\mathrm{CH}_{3} \mathrm{O}$ & D-glucopentyl & 69 & 26 \\
$\mathbf{6 2}$ & $4-\mathrm{CH}_{3} \mathrm{O}$ & D-xylobutyl & 82 & 35 \\
$\mathbf{6 3}$ & $2-\mathrm{CH}_{3}$ & D-glucopentyl & 59 & 22 \\
$\mathbf{6 4}$ & $2-\mathrm{CH}_{3}$ & D-xylobutyl & 76 & 30 \\
Virazole & & & 100 & 100 \\
\hline
\end{tabular}

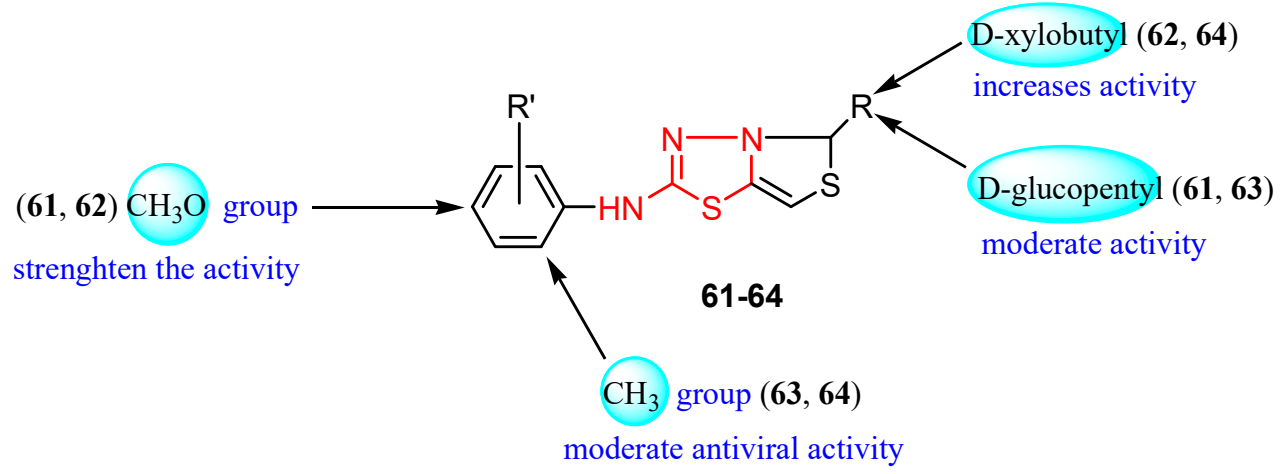

Figure 10. Influence of substituents of 1,3,4-thiadiazole derivatives 61-64 on antiviral activity.

\section{Conclusions}

The research focused on 1,3,4-thiadiazole derivatives indicates a broad spectrum of pharmacological activities associated with good physicochemical and pharmacokinetic properties. This article presents a literature review of 2-amino-1,3,4-thiadiazole derivatives that have been evaluated for antiviral activity against several viral strains. In addition to the 2-amino-1,3,4-thiadiazole moiety, antiviral activity is also dependent on the nature of the substituents, and structure-activity studies have shown the most efficient substituents for antiviral activity in each class. Based on the literature data, the 2-amino-1,3,4-thiadiazole scaffold may be considered a possible pharmacophore group that can be incorporated into the structure of known compounds to enhance antiviral activity and contributes to the search and development of new medicines as an alternative to the treatment of viral infections.

Funding: This research received no external funding.

Conflicts of Interest: The author declares no conflicts of interest. 


\section{References}

1. Beale, J.M., Jr. Antiviral agents. In Wilson and Gisvold's Textbook of Organic Medicinal and Pharmaceutical Chemistry, 12th ed.; Beale, J.M., Jr., Block, J.H., Eds.; Lippincott Williams and Wilkins: Baltimore, MD, USA, 2011; pp. 330-336.

2. Rohwer, F.; Barrot, K. Viral information. Biol. Philos. 2013, 28, 283-297. [CrossRef]

3. Woster, P.M. Antiviral agents and protease inhibitors. In Foye's Principles of Medicinal Chemistry, 7th ed.; Lemke, T.L., Williams, D.A., Roche, V.F., Zito, S.W., Eds.; Lippincott Williams and Wilkins, Wolters Kluwer: Baltimore, MD, USA, 2013; pp. 1274-1302.

4. Berzofsky, J.A.; Ahlers, J.D.; Janik, J.; Morris, J.; Oh, S.K.; Terabe, M.; Belyakov, I.M. Progress on new vaccine strategies against chronic viral infections. J. Clin. Invest. 2004, 114, 450-462. [CrossRef] [PubMed]

5. World Health Organization. Human papillomavirus vaccines: WHO position paper, May 2017, Weekly epidemiological record. Available online: http://www.who.int/wer (accessed on 11 January 2020).

6. El-Essawy, F.A.; El-Sayed, W.A.; El-Kafrawy, S.A.; Morshedy, A.S.; Abdel-Rahman, A.H. Anti-Hepatitis B virus activity of new 1,2,4-triazol-2-yl- and1,3,4-oxadiazol-2-yl-2-pyridinone derivatives. Z. Naturforsch. 2008, 63c, 667-674. [CrossRef] [PubMed]

7. Tonelli, M.; Cichero, E. Fight against H1N1 Influenza A virus: recent insights towards the development of druggable compounds. Curr. Med. Chem. 2016, 23, 1802-1817. [CrossRef] [PubMed]

8. Diaba, F.; Montiel, J.A.; Serban, G.; Bonjoch, J. Synthesis of normorphans through an efficient intramolecular carbamoylation of ketones. Org. Lett. 2015, 17, 3860-3863. [CrossRef]

9. Serban, G.; Abe, H.; Takeuchi, Y. Synthetic studies of substituted pyridine aldehydes as intermediates for the synthesis of toddaquinoline, its derivatives and other natural products. Heterocycles 2011, 83, 1989-2000. [CrossRef]

10. Serban, G.; Abe, H.; Takeuchi, Y.; Harayama, T. A new approach to the benzopyridoxepine core by metal mediated intramolecular biaryl ether formation. Heterocycles 2008, 75, 2949-2958. [CrossRef]

11. Serban, G.; Shigeta, Y.; Nishioka, H.; Abe, H.; Takeuchi, Y.; Harayama, T. Studies toward the synthesis of toddaquinoline by intramolecular cyclization. Heterocycles 2007, 71, 1623-1630. [CrossRef]

12. Gupta, R. Biological significance of nitrogen containing heterocyclic compounds-a mini review. IJCA 2015, $8,18-23$.

13. Joule, J.A. Natural products containing nitrogen heterocycles—some highlights 1990-2015. In Advances in Heterocyclic Chemistry: Heterocyclic Chemistry in the 21st Century-A Tribute to Alan Katritzky, 1st ed.; Scriven, E.F.V., Ramsden, C.A., Eds.; Academic Press Elsevier: Cambridge, UK, 2016; Volume 119, pp. 81-106.

14. Takashima, K.; Hayakawa, D.; Gouda, H.; Toyooka, N. Formal syntheses of (-)-Lepadiformines A, C and (-)-Fasicularin. J. Org. Chem. 2019, 84, 5222-5229. [CrossRef]

15. Vitaku, E.; Smith, D.T.; Njardarson, J.T. Analysis of the structural diversity, substitution patterns, and frequency of nitrogen heterocycles among U.S. FDA approved pharmaceuticals. J. Med. Chem. 2014, 57, 10257-10274. [CrossRef] [PubMed]

16. Shukla, P.K.; Verma, A.; Mishra, P. Significance of nitrogen heterocyclic nuclei in the search of pharmacological active compounds. In New Perspective in Agricultural and Human Health; Shukla, R.P., Mishra, R.S., Tripathi, A.D., Yadav, A.K., Tiwari, M., Mishra, R.R., Eds.; Bharti Publication: New Delhi, India, 2017; pp. 100-126.

17. Rajput, A.P.; Kankhare, A.R. Synthetic utility of azaheterocycles: A short review. Int. J. Pharm. Sci. Invent. 2017, 6, 19-25.

18. De Clercq, E.; Li, G. Approved antiviral drugs over the past 50 years. Clin. Microbiol. Rev. 2016, 29, 695-747. [CrossRef] [PubMed]

19. Razonable, R.R. Antiviral drugs for viruses other than human immunodeficiency virus. Mayo Clin. Proc. 2011, 86, 1009-1026. [CrossRef] [PubMed]

20. Serban, G.; Stanasel, O.; Serban, E.; Bota, S. 2-Amino-1,3,4-thiadiazole as a potential scaffold for promising antimicrobial agents. Drug Des. Devel. Ther. 2018, 12, 1545-1566. [CrossRef]

21. Schenone, S.; Brullo, C.; Bruno, O.; Bondavalli, F.; Ranise, A.; Filippelli, W.; Rinaldi, B.; Capuano, A.; Falcone, G. New 1,3,4-thiadiazole derivatives endowed with analgesic and anti-inflammatory activities. Bioorg Med Chem. 2006, 14, 1698-1705. [CrossRef] 
22. Labanauskas, L.; Kalcas, V.; Udrenaite, E.; Gaidelis, P.; Brukstus, A.; Dauksas, A. Synthesis of 3-(3,4-dimethoxyphenyl)-1H-1,2,4-triazole-5-thiol and 2-amino-5-(3,4-dimethoxyphenyl)-1,3,4-thiadiazole derivatives exhibiting anti-inflammatory activity. Pharmazie 2001, 56, 617-619.

23. Clerici, F.; Pocar, D.; Guido, M.; Loche, A.; Perlini, V.; Brufani, M. Synthesis of 2-amino-5-sulfanyl1,3,4-thiadiazole derivatives and evaluation of their antidepressant and anxiolytic activity. J Med Chem. 2001, 44, 931-936. [CrossRef]

24. Basso, A.; Liu, M.; Dai, C.; Gray, K.; Nale, L.; Tevar, S.; Lee, S.; Liang, L.; Ponery, A.; Yaremko, B.; et al. SCH 2047069, a novel oral kinesin spindle protein inhibitor, shows single-agent antitumor activity and enhances the efficacy of chemotherapeutics. Mol. Cancer Ther. 2019, 9, 2993-3002. [CrossRef]

25. Dawood, K.M.; Farghaly, T.A. Thiadiazole inhibitors: A patent review. Expert Opin. Ther. Pat. 2017, 27, 477-505. [CrossRef]

26. Haider, S.; Alam, M.S.; Hamid, H. 1,3,4-Thiadiazoles: a potent multi targeted pharmacological scaffold. Eur. J. Med. Chem. 2015, 92, 156-177. [CrossRef] [PubMed]

27. Serban, G. Future prospects in the treatment of parasitic diseases: 2-amino-1,3,4-thiadiazoles in leishmaniasis. Molecules 2019, 24, 1557. [CrossRef] [PubMed]

28. Li, Y.; Geng, J.; Liu, Y.; Yu, S.; Zhao, G. Thiadiazole-A promising structure in Medicinal Chemistry. ChemMedChem 2013, 8, 27-41. [CrossRef] [PubMed]

29. Senff-Ribeiro, A.; Echevarria, A.; Silva, E.F.; Franco, C.R.C.; Veiga, S.S.; Oliveira, M.B.M. Cytotoxic effect of a new 1,3,4-thiadiazolium mesoionic compound (MI-D) on cell lines of human mellanoma. Br. J. Cancer 2004, 91, 297-304. [CrossRef] [PubMed]

30. Wermuth, C.G. Are pyridazines privileged structures? Med.Chem.Commun. 2011, 2, 935-941. [CrossRef]

31. Biziere, K.; Worms, P.; Kan, J.P.; Mandel, P.; Garattini, S.; Roncucci, R. Minaprine, a new drug with antidepressant properties. Drugs Exp. Clin. Res. 1985, 11, 831-840. [PubMed]

32. Ueno, S.; Bracamontes, J.; Zorumski, C.; Weiss, D.S.; Steinbach, J.H. Bicuculline and gabazine are allosteric inhibitors of channel opening of the GABA A receptor. J. Neurosci. 1997, 17, 625-634. [CrossRef] [PubMed]

33. Holla, B.S.; Poorjary, K.N.; Rao, B.S.; Shivananda, M.K. New bis-aminomercaptotriazoles and bis-triazolothiadiazoles as possible anticancer agents. Eur. J. Med. Chem. 2002, 37, 511-517. [CrossRef]

34. Yousif, E.; Majeed, A.; Al-Sammarrae, K.; Salih, N.; Salimon, J.; Abdullah, B. Metal complexes of Schiff base: preparation, characterization and antibacterial activity. Arabian J. Chem. 2013, 5. [CrossRef]

35. Juszczak, M.; Matysiak, J.; Brzana, W.; Niewiadomy, A.; Rzeski, W. Evaluation of antiproliferative activity of 2-(monohalogenophenylamino)-5-(2,4-dihydroxyphenyl)-1,3,4-thiadiazoles. Arzneim. Forsch. Drug Res. 2008, 58, 353-357. [CrossRef]

36. Matysiak, J. Evaluation of antiproliferative effect in vitro of some 2-amino-5-(2,4-dihydroxyphenyl)-1,3,4thiadiazole derivatives. Chem. Pharm. Bull. 2006, 54, 988-991. [CrossRef] [PubMed]

37. Yoosefian, M.; Chermahini, Z.J.; Raissi, H.; Mola, A.; Sadeghi, M. A theoretical study on the structure of 2-amino-1,3,4-thiadiazole and its 5-substituted derivatives in the gas phase, water, THF and DMSO solutions. J. Mol. Liq. 2015, 203, 137-142. [CrossRef]

38. Serban, G. 2-Amino-1,3,4-thiadiazoles as prospective agents in trypanosomiasis and other parasitoses. Acta Pharm. 2020, 70, 259-290. [CrossRef] [PubMed]

39. Serban, G. 5-Arylamino-1,3,4-thiadiazol-2-yl acetic acid esters as intermediates for the synthesis of new bisheterocyclic compounds. Farmacia 2015, 63, 146-149.

40. Serban, G.; Coman, M.; Curea, E. Synthesis of some heterocyclic nitro-coumarins by Knoevenagel condensation. Farmacia 2005, 53, 78-84.

41. Serban, G.; Matinca, D.; Bradea, O.; Gherman, L.; Coman, M.; Curea, E. The study of the biological activity of some heterocyclic coumarins. Farmacia 2005, 53, 91-99.

42. Serban, G.; Suciu, A.; Coman, M.; Curea, E. Synthesis and physical-chemical study of some 3-(5-arylamino-1,3,4-thiadiazol-2-yl)cou-marins. Farmacia 2002, 50, 50-54.

43. Horvath, T.; Serban, G.; Cuc, S. Synthesis of new 2-phenylamino-5-[( $\alpha$-acylamino $)$-p-X-stiryl] -1,3,4-thiadiazole compounds. Farmacia 2014, 62, 422-427.

44. Serban, G.; Coman, M.; Curea, E.; Proinov, L. Synthesis and description of some heterocyclic coumarins. Farmacia 2001, 49, 45-52. 
45. Global AIDS Update 2016. Joint United Nations Programme on HIV/AIDS, Geneva, Switzerland. Available online: https://www.unaids.org/sites/default/files/media_asset/global-AIDS-update-2016en.pdf (accessed on 17 July 2018).

46. Sharma, P.C.; Sinhmar, A.; Sharma, A.; Rajak, H.; Pathak, D.P. Medicinal significance of benzothiazole scaffold: An insight view. J. Enzyme Inhib. Med. Chem. 2013, 28, 240-266. [CrossRef]

47. Xiaohe, Z.; Yu, Q.; Hong, Y.; Xiuqing, S.; Rugang, Z. Synthesis, biological evaluation and molecular modeling studies of $N$-aryl-2-arylthioacetamides as non-nucleoside HIV-1 reverse transcriptase inhibitors. Chem. Biol. Drug Des. 2010, 76, 330-339. [CrossRef] [PubMed]

48. Harms, A. Non-nucleoside reverse transcriptase inhibitors. In The art of drug synthesis; Johnson, D.S., Li, J.J., Eds.; Wiley Interscience, John Wiley and Sons, Inc., Hoboken: New Jersey, NJ, USA, 2007; p. 84.

49. Tatar, E.; Kucukguzel, S.G.; Karakus, S.; De Clercq, E.; Andrei, G.; Snoeck, R.; Pannecouque, C.; OktemOkullu, S.; Unubol, N.; Kocagoz, T.; et al. Synthesis and biological evaluation of some new 1,3,4-thiadiazole and 1,2,4-triazole derivatives from $L$-methionine as antituberculosis and antiviral agents. Marmara Pharm. J. 2015, 19, 88-102. [CrossRef]

50. Wit, F.W.N.M.; Lange, J.M.A.; Volberding, P.A. New HIV Drug Development. In Global HIV/AIDS Medicine; Volberding, P.A., Sande, M.A., Greene, W.C., Lange, J.M.A., Eds.; Elsevier: Philadelphia, PA, USA, 2008; pp. 123-134.

51. Schiller, D.S.; Youssef-Bessler, M. Etravirine: A second-generation nonnucleoside reverse transcriptase inhibitor (NNRTI) active against NNRTI-resistant strains of HIV. Clin. Ther. 2009, 31, 692-704. [CrossRef] [PubMed]

52. Miller, C.D.; Crain, J.; Tran, B.; Patel, N. Rilpivirine: A new addition to the anti-HIV-1 armamentarium. Drugs Today 2011, 47, 5-15. [CrossRef] [PubMed]

53. Doravirine combination pill looks good for initial HIV treatment. Available online: https: //www.aidsmap.com/news/jul-2017/doravirine-combination-pill-looks-good-initial-hiv-treatment;http: //www.aidsmap.com/Doravirine-combination-pill-looks-good-for-initial-HIV-treatment/pagee3160520 (accessed on 5 June 2018).

54. Gatell, J.M.; Raffi, F.; Plettenberg, A.; Smith, D.; Portilla, J.; Hoffmann, C.; Arasteh, K.; Thompson, M.; Xu, X.; Teppler, H. Doravirine 100 mg QD vs Efavirenz + TDF/FTC in ART-Naive HIV+ Patients: Week 48 Results. In Proceedings of the Conference on Retroviruses and Opportunistic Infections, Boston, MA, USA, 22-25 February 2016. abstract number 470.

55. FDA Accepts New Drug Applications for Merck's Doravirine, the Company's Investigational Non-Nucleoside Reverse Transcriptase Inhibitor (NNRTI), for Treatment of HIV-1 Infection. Available online: http://investors.merck.com/news/press-release-details/2018/FDA-Accepts-New-Drug-Applications-forMercks-Doravirine-the-Companys-Investigational-Non-Nucleoside-Reverse-Transcriptase-InhibitorNNRTI-for-Treatment-of-HIV-1-Infection/default.aspx (accessed on 5 June 2018).

56. FDA approves Merck's Pifeltro (doravirine). Available online: https://www.drugs.com/newdrugs/fdaapproves-merck-s-pifeltro-doravirine-hiv-1-appropriate-patients-4815.html (accessed on 6 November 2019).

57. Merck's Pifeltro (doravirine) and Delstrigo (doravirine/lamivudine/tenofovir disoproxil fumarate) receive FDA approval for use in appropriate adults living with HIV-1 who are virologically suppressed. 20 September 2019. Available online: https://investors.merck.com/news/press-release-details/2019/Mercks-PIFELTROdoravirine-and-DELSTRIGO-doravirinelamivudinetenofovir-disoproxil-fumarate-Receive-US-FDA-

Approval-for-Use-in-Appropriate-Adults-Living-with-HIV-1-Who-Are-Virologically-Suppressed/default. aspx (accessed on 6 November 2019).

58. Margolis, D.A.; Eron, J.J.; DeJesus, E.; White, S.; Wannamaker, P.; Stancil, B.; Johnson, M. Unexpected finding of delayed-onset seizures in HIV-positive, treatment-experienced subjects in the Phase IIb evaluation of fosdevirine (GSK2248761). Antivir. Ther. 2014, 19, 69-78. [CrossRef]

59. Vernazza, P.; Wang, C.; Pozniak, A.; Weil, E.; Pulik, P.; Cooper, D.A.; Kaplan, R.; Lazzarin, A.; Valdez, H.; Goodrich, J.; et al. Efficacy and safety of lersivirine (UK-453,061) versus efavirenz in antiretroviral treatment-naive HIV-1 infected patients: week 48 primary analysis results from an ongoing, multicenter, randomized, double-blind, Phase Ilb trial. J. Acquir. Immune Defic. Syndr. 2013, 62, 171-179. [CrossRef]

60. Platten, M.; Fatkenheuer, G. Lersavirine-a new drug for HIV infection therapy. Expert. Opin. Investig. Drugs 2013, 22, 1687-1694. [CrossRef] 
61. Sacks, D.; Ledwaba, J.; Morris, L.; Hunt, G.M. Rapid detection of common HIV-1 drug resistance mutations by use of high-resolution melting analysis and unlabeled probes. J. Clin. Microbiol. 2017, 55, 122-133. [CrossRef]

62. Yahi, N.; Tamalet, C.; Tourres, C.; Tivoli, N.; Ariasi, F.; Volot, F.; Gastaut, J.A.; Gallais, H.; Moreau, J.; Fantini, J. Mutation patterns of the reverse transcriptase and protease genes in Human Immunodeficiency Virus type 1-infected patients undergoing combination therapy: survey of 787 sequences. J. Clin. Microbiol. 1999, 37, 4099-4106. [CrossRef]

63. Hu, Y.; Li, C.Y.; Wang, X.M.; Yang, Y.H.; Zhu, H.L. 1,3,4-Thiadiazole: synthesis, reactions and applications in medicinal, agricultural, and materials chemistry. Chem. Rev. 2014, 114, 5572-5610. [CrossRef]

64. Szulczyk, D.; Tomaszewski, P.; Jozwiak, M.; Koziol, A.E.; Lis, T.; Collu, D.; Iuliano, F.; Struga, M. Synthesis and biological activities of ethyl 2-(2-pyridylacetate) derivatives containing thiourea, 1,2,4-triazole, thiadiazole and oxadiazole moieties. Molecules 2017, 22, 409. [CrossRef] [PubMed]

65. Akhtar, T.; Hameed, S.; Al-Masoudi, N.A.; Khan, K.M. Synthesis and anti-HIV activity of new chiral 1,2,4-triazoles and 1,3,4-thiadiazoles. Heteroatom Chem. 2007, 18, 316-322. [CrossRef]

66. Hamad, N.S.; Al-Haidery, N.H.; Al-Masoudi, I.A.; Sabri, M.; Sabri, L.; Al-Masoudi, N.A. Amino acid derivatives, part 4: synthesis and anti-HIV activity of new naphthalene derivatives. Arch. Pharm. Chem. Life Sci. 2010, 343, 397-403. [CrossRef] [PubMed]

67. Wang, Z.; Wu, B.; Kuhen, K.L.; Bursulaya, B.; Nguyen, T.N.; Nguyen, D.G.; He, Y. Synthesis and biological evaluations of sulfanyltriazoles as novel HIV-1 non-nucleoside reverse transcriptase inhibitors. Bioorg. Med. Chem. Lett. 2006, 16, 4174-4177. [CrossRef] [PubMed]

68. Muraglia, E.; Kinzel, O.D.; Laufer, R.; Miller, M.D.; Moyer, G.; Munshi, V.; Orvieto, F.; Palumbi, M.C.; Pescatore, G.; Rowley, M.; et al. Tetrazole thioacetanilides: potent non-nucleoside inhibitors of WT HIV reverse transcriptase and its K103N mutant. Bioorg. Med. Chem. Lett. 2006, 16, 2748-2752. [CrossRef] [PubMed]

69. Zhan, P.; Liu, X.; Cao, Y.; Wang, Y.; Pannecouque, C.; De Clercq, E. 1,2,3-Thiadiazole thioacetanilides as a novel class of potent HIV-1 non-nucleoside reverse transcriptase inhibitors. Bioorg. Med. Chem. Lett. 2008, 18, 5368-5371. [CrossRef] [PubMed]

70. Zhang, Z.; Xu, W.; Koh, Y.H.; Shim, J.H.; Girardet, J.L.; Yeh, L.T.; Hamatake, R.K.; Hong, Z. A novel non-nucleoside analogue that inhibits human immunodeficiency virus type 1 isolates resistant to current non-nucleoside reverse transcriptase inhibitors. Antimicrob. Agents Chemother. 2007, 51, 429-437. [CrossRef]

71. Huang, Y.; Zhao, L.; Jia, B.; Wu, L.; Li, Y.; Curthoys, N.; Zheng, J.C. Glutaminase dysregulation in HIV-1-infected human microglia mediates neurotoxicity: relevant to HIV-1 associated neurocognitive disorders. J. Neurosci. 2011, 31, 15195-15204. [CrossRef]

72. Zhao, J.; Lopez, A.L.; Erichsen, D.; Herek, S.; Cotter, R.L.; Curthoys, N.P.; Zheng, J. Mitochondrial glutaminase enhances extracellular glutamate production in HIV-1-infected macrophages: Linkage to HIV-1 associated dementia. J. Neurochem. 2004, 88, 169-180. [CrossRef]

73. Stumvoll, M.; Perriello, G.; Meyer, C.; Gerich, J. Role of glutamine in human carbohydrate metabolism in kidney and other tissues. Kidney Int. 1999, 55, 778-792. [CrossRef]

74. Smith, R.J. Glutamine metabolism and its physiological importance. J. Parenter. Enteral. Nutr. 1990, 14, 40S-44S. [CrossRef] [PubMed]

75. Bromley, S.D.; Bennett, M.K.; Gross, M.I.; Li, J.; Chen, L.; Goyal, B.; Laidig, G.; Stanton, T.F.; Sjogren, E.B. Treatment of viral infections with inhibitors of glutaminase. PCT Int. Appl. PCT/US2014/061746; WO 2015/061432 A1. 2015.

76. Newsholme, P.; Lima, M.M.R.; Procopio, J.; Pithon-Curi, T.C.; Doi, S.Q.; Bazotte, R.B.; Curi, R. Glutamine and glutamate as vital metabolites. Braz. J. Med. Biol. Res. 2003, 36, 153-162. [CrossRef] [PubMed]

77. Behar, K.L.; Rothman, D.L. In vivo NMR studies of glutamate-GABA-glutamine cycling in rodent and human cortex: the central role of glutamine. J. Nutr. 2001, 131, 2498-2504. [CrossRef] [PubMed]

78. Erdmann, N.; Zhao, J.; Lopez, A.L.; Herek, S.; Curthoys, N.; Hexum, T.D.; Tsukamoto, T.; Ferraris, D.; Zheng, J. Glutamate production by HIV-1 infected human macrophage is blocked by the inhibition of glutaminase. J. Neurochem. 2007, 102, 539-549. [CrossRef]

79. Babayo, A.; Thairu, Y.; Nasir, I.A.; Baba, M.M. Serological evidence and sociodemographic risk factors of recent cytomegalovirus infection in pregnant women attending a tertiary hospital in Maiduguri, Nigeria. J. Med. Microbiol. Infec. Dis. 2014, 2, 49-55. 
80. Forbes, B.A. Acquisition of cytomegalovirus infection: An update. Clin. Microbiol. Rev. 1989, 2, $204-216$. [CrossRef]

81. Spruance, S.L. Viral infections. In The Merck Manual of Medical Information: Second Home Edition; Beers, M.H., Ed.; Merck Research Laboratories, Merck and Co., Inc.: Whitehouse Station, NJ, USA, 2003; p. 1164.

82. Centers for Disease Control and Prevention. Cytomegalovirus (CMV) and Congenital CMV Infection. Available online: https://www.cdc.gov/cmv/overview.html (accessed on 11 July 2018).

83. Tan, B.H. Cytomegalovirus treatment. Curr. Treat. Options Infect. Dis. 2014, 6, 256-270. [CrossRef]

84. McGavin, J.K.; Goa, K.L. Ganciclovir: An update of its use in the prevention of cytomegalovirus infection and disease in transplant recipients. Drugs 2001, 61, 1153-1183. [CrossRef]

85. Sakamoto, H.; Hirano, M.; Nose, K.; Ueno, S.; Oki, T.; Sugimoto, K.; Nishioka, T.; Kusunoki, S.; Nakamura, Y. A case of severe ganciclovir-induced encephalopathy. Case Rep. Neurol. 2013, 5, 183-186. [CrossRef]

86. Thaisrivongs, S.; Turner, S.R. 1,3,4-Thiadiazoles useful for the treatment of CMV infections. US Patent 6,150,385, 2000.

87. World Health Organization. Battle against Respiratory Viruses (BRaVe) initiative. Available online: http://www.who.int/influenza/patient_care/clinical/brave/en/ (accessed on 14 June 2018).

88. World Health Organization. Research needs for the battle against respiratory viruses (BRAve). Background document 2013. Available online: http://www.who.int/influenza/patient_care/clinical/BRaVe_Research_ Agenda_2013.pdf (accessed on 14 June 2018).

89. Bellos, A.; Mulholland, K.; O’Brien, K.L.; Qazi, S.A.; Gayer, M.; Checchil, F. The burden of acute respiratory infections in crisis-affected populations: A systematic review. Confl. Health 2010, 4, 1-12. [CrossRef]

90. Straliotto, S.M.; Siqueira, M.M.; Muller, R.L.; Fischer, G.B.; Cunha, M.L.T.; Nestor, S.M. Viral etiology of acute respiratory infections among children in Porto Alegre, RS, Brazil. Rev. Soc. Bras. Med. Tro. 2002, 35, $283-291$. [CrossRef] [PubMed]

91. Da Silva, R.C.; da Silva Mendes, G.; Rojas, M.A.; Amorim, A.R.; Couceiro, J.N.; Lupi, O.; Elabras, J.; Pires, G.; Valle, S.; Santos, N. Frequency of viral etiology in symptomatic adult upper respiratory tract infections. Braz. J. Infect. Dis. 2015, 19, 30-35. [CrossRef] [PubMed]

92. Fendrick, A.M.; Monto, A.S.; Nightengale, B.; Sarnes, M. The economic burden of non-influenza-related viral respiratory tract infections in the United States. Arch. Intern. Med. 2003, 163, 487-494. [CrossRef] [PubMed]

93. Johnson, D.S.; Li, J.J. Neuraminidase inhibitors for influenza: oseltamivir phosphate (Tamiflu) and zanamivir (Relenza). In The art of drug synthesis; Johnson, D.S., Li, J.J., Eds.; Wiley Interscience, John Wiley and Sons, Inc., Hoboken: New Jersey, NJ, USA, 2007; pp. 95-96.

94. Al-Muharrmi, Z. Understanding the Influenza A H1N1 2009 pandemic. SQU Med. J. 2010, 10, 187-195.

95. Tonelli, M.; Naesens, L.; Gazzarrini, S.; Santucci, M.; Cichero, E.; Tasso, B.; Moroni, A.; Costi, M.P.; Loddo, R. Host dihydrofolate reductase (DHFR)-directed cycloguanil analogues endowed with activity against influenza virus and respiratory syncytial virus. Eur. J. Med. Chem. 2017, 135, 467-478. [CrossRef]

96. Francesconi, V.; Giovannini, L.; Santucci, M.; Cichero, E.; Costi, M.P.; Naesens, L.; Giordanetto, F.; Tonelli, M. Synthesis, biological evaluation and molecular modeling of novel azaspiro dihydrotriazines as influenza virus inhibitors targeting the host factor dihydrofolate reductase (DHFR). Eur. J. Med. Chem. 2018, 155, 229-243. [CrossRef]

97. World Health Organization. Fact sheets on sustainable development goals: health target, Viral hepatitis, World Health Organization 2017, Copenhagen, Denmark, www.euro.who.int/sdgs. Available online: http://www.euro.who.int/_data/assets/pdf_file/0003/348222/Fact-sheet-SDG-viral-hepatitis-FINALen.pdf?ua=1 (accessed on 23 January 2020).

98. World Health Organization. Hepatitis B in the WHO European Region, Fact sheet - July 2019, World Health Organization 2019. Available online: http://www.euro.who.int/_data/assets/pdf_file/0007/377251/ Fact-Sheet-Hepatitis-B_2019-ENG.pdf?ua=1 (accessed on 23 January 2020).

99. FDA. Hepatitis B and C treatments. Available online: https://www.fda.gov/patients/hepatitis-b-c/hepatitis-band-c-treatments (accessed on 23 January 2020).

100. Kurkela, S.; Ratti, O.; Huhtamo, E.; Uzcategui, N.; Nuorti, J.P.; Laakkonen, J.; Manni, T.; Helle, P.; Vaheri, A.; Vapalahti, O. Sindbis virus infection in resident birds, migratory birds, and humans, Finland. Emerg. Infect. Dis. 2008, 14, 41-47. [CrossRef] 
101. Kucukguzel, S.G.; Kucukguzel, I.; Tatar, E.; Rollas, S.; Sahin, F.; Gulluce, M.; De Clercq, E.; Kabasakal, L. Synthesis of some novel heterocyclic compounds derived from diflunisal hydrazide as potential anti-infective and anti-inflammatory agents. Eur. J. Med. Chem. 2007, 42, 893-901. [CrossRef]

102. Bonina, L.; Orzalesi, G.; Merendino, R.; Arena, A.; Mastroeni, P. Structure-activity relationships of new antiviral compounds. Antimicrob. Agents Chemother. 1982, 22, 1067-1069. [CrossRef]

103. Streissle, G.; Paesseus, A.; Oediger, H. New antiviral compounds. In Advances in Virus Research; Maramorosch, K., Murphy, F.A., Shatkin, A.J., Eds.; Academic Press., Elsevier: London, UK, 1985; Volume 30, p. 115.

104. Cui, T.; Chum, M.P.; Lam, Y.; Gao, Y. Compounds for use as anti-viral agents. Singapore Pat. Appl. SG 162629 A1 20100729. 2010.

105. Yadav, L.D.S.; Singh, S. Synthesis of antiviral acyclic C-nucleosides incorporating thiazolo-1,3,4-oxa(thia)diazole or thiazolo-1,2,4-triazole structure as a nucleobase. Indian J. Chem. 2001, 40B, 440-442. [CrossRef]

(C) 2020 by the author. Licensee MDPI, Basel, Switzerland. This article is an open access article distributed under the terms and conditions of the Creative Commons Attribution (CC BY) license (http://creativecommons.org/licenses/by/4.0/). 